\title{
Characterization of organic ambient aerosol during MIRAGE 2006 on three platforms
}

\author{
S. Gilardoni ${ }^{1, *}$, S. Liu ${ }^{1}$, S. Takahama ${ }^{1}$, L. M. RusselI ${ }^{1}$, J. D. Allan ${ }^{2}$, R. Steinbrecher ${ }^{3}$, J. L. Jimenez ${ }^{4}$, P. F. De Carlo ${ }^{4}$,**, \\ E. J. Dunlea ${ }^{4}$, and D. Baumgardner ${ }^{5}$ \\ ${ }^{1}$ Scripps Inst. of Oceanography, University of California, San Diego, La Jolla, California, USA \\ ${ }^{2}$ National Centre for Atmospheric Science, School of Earth, Atmospheric and Environmental Sciences, \\ The University of Manchester, Manchester, UK \\ ${ }^{3}$ Institute of Meteorology and Climate Research, Forschungszentrum, Karlsruhe GmbH (IMK-IFU), Germany \\ ${ }^{4}$ Cooperative Institute for Research in the Environmental Sciences (CIRES), University of Colorado, Boulder, Colorado, USA \\ ${ }^{5}$ Centro de Ciencias de la Atmósfera, Universidad Nacional Autónoma de México, Mexico City, Mexico \\ *now at: Joint Research Center, Institute of Environment and Sustainability, Climate Change Unit, Ispra, Italy \\ ** now at: Paul Scherrer Institut, Switzerland
}

Received: 5 February 2009 - Published in Atmos. Chem. Phys. Discuss.: 10 March 2009

Revised: 11 June 2009 - Accepted: 20 July 2009 - Published: 3 August 2009

\begin{abstract}
Submicron atmospheric aerosol particles were collected during the Megacity Initiative: Local and Global Research Observation (MILAGRO) in March 2006 at three platforms located in the Mexico City urban area (at the Mexico City Atmospheric Monitoring System building SIMAT), at about $60 \mathrm{~km}$ south-east of the metropolitan area (Altzomoni in the Cortes Pass), and on board the NCAR C130 aircraft. Organic functional group and elemental composition were measured by FTIR and XRF. The average organic mass $(\mathrm{OM})$ concentration, calculated as the sum of organic functional group concentrations, was $9.9 \mu \mathrm{g} \mathrm{m}^{-3}$ at SIMAT, $6.6 \mu \mathrm{g} \mathrm{m}^{-3}$ at Altzomoni, and $5.7 \mu \mathrm{g} \mathrm{m}^{-3}$ on the C130. Aliphatic saturated C-C-H and carboxylic acid $\mathrm{COOH}$ groups dominated $\mathrm{OM}$ (more than $60 \%$ ) at the ground sites. On the $\mathrm{C} 130$, a non-acid carbonyl $\mathrm{C}=\mathrm{O}$, carboxylic acid $\mathrm{COOH}$, and amine $\mathrm{NH}_{2}$ groups were observed in concentrations above detection limit only outside the Mexico City basin. From the elemental composition of SIMAT samples, we estimated the upper bound of average contribution of biomass burning to the organic carbon (OC) as $33-39 \%$. The average OM/OC ratio was 1.8 at SIMAT, 2.0 at Altzomoni, and 1.6-1.8 on the $\mathrm{C} 130$. On the aircraft, higher OM/OC ra-
\end{abstract}

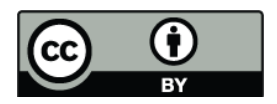

Correspondence to: L. M. Russell (lmrussell@ucsd.edu ) tios were measured outside of the Mexico City basin, north of the urban area, along the city outflow direction. The average carboxylic acid to aliphatic saturated ratio at SIMAT reflected a local increase of oxidized functional group concentration in aged particles.

\section{Introduction}

Atmospheric aerosols impact environmental quality on short time scales by affecting human health and reducing visibility (Chan et al., 1999; Pope et al., 1995) . Atmospheric aerosols also affect climate by scattering and absorbing incoming solar radiation (Charlson et al., 1992; Lindberg, 1975) and by influencing cloud formation and properties (McFiggans et al., 2006). The impacts of atmospheric aerosols on the environment depend on particle physical properties and chemical composition.

Organic aerosols represent a large fraction of fine atmospheric aerosols, both in urban and rural locations (Hildemann et al., 1994; Putaud et al., 2004; Zhang et al., 2007). The organic fraction of fine aerosol can include saturated and unsaturated aliphatic compounds, aromatic compounds, alcohols, ketones, aldehydes, carboxylic acids, amines, sugars, polyols, and organic sulfur compounds (Seinfeld and Pandis, 1998). Organic molecules that are emitted directly into

Published by Copernicus Publications on behalf of the European Geosciences Union. 
the atmosphere contribute to the Primary Organic Aerosol (POA); Secondary Organic Aerosol (SOA) is formed by oxidation of organic species in the gas phase followed by condensation of the products (homogenous oxidation), by oxidation of precursors in the aerosol phase (cloud processing or heterogeneous oxidation), or by oxidation and recondensation of volatilized primary organic aerosol (Robinson et al., 2007). SOA is typically composed of molecules containing oxygenated functional groups, including organic hydroxyl and carbonyl groups (Kawamura and Ikushima, 1993; Kawamura and Yasui, 2005). Aged and processed aerosols, which are dominated by SOA over POA, are expected to show a high content of oxygenated functional groups and consequently a high organic mass to organic carbon ratio (Aiken et al., 2008; Turpin and Lim, 2001).

The Mexico City metropolitan area is one of the most populated areas of the world with a population larger than 18 million in 2005 . The city elevation is $2240 \mathrm{~m}$ above sea level, resulting in lower oxygen availability and less efficient combustion. The low combustion efficiency, older vehicle fleet, and the vehicle engine tuning (Beaton et al., 1992) release a large amount of pollutants into the atmosphere as a consequence of fossil fuel and biomass burning (Molina and Molina, 2002). In addition to anthropogenic activities, sulfate from Popocateptl volcano (Marquez et al., 2005; Raga et al., 1999; Fast et al., 2007; Grutter et al., 2008), dust (Johnson et al., 2006; Miranda et al., 2004), and forest fires (Yokelson et al., 2007) contribute to the high level of particulate matter. Mexico City is located in a basin on the central plateau of Mexico surrounded by mountain ranges on the west, south and east sides.

This paper introduces the results of analysis of organic aerosol samples collected in March 2006 at three platforms during the Megacity Initiative: Local and Global Research Observation (MILAGRO). The scope of the experiment was to observe the effects of transport and aging of urban particles on the composition of the organic aerosol (Molina et al., 2008). MILAGRO is the largest of a series of international campaigns in and around Mexico City, which also includes IMADA-AVER in 1997 (Edgerton et al., 1999), MCMA2003 (Molina et al., 2007), and MIRAGE (Megacities Impact on Regional and Global Environment) in 2006. This study investigates the composition of organic aerosols in Mexico City and in surrounding areas by Fourier Transform Infrared Spectrometry (FTIR). The composition of organic aerosol is still poorly characterized, because separating and quantifying the complex mixture of organics present in atmospheric particles is not possible with present techniques. Identification of individual molecules by gas-chromatographic techniques resolves only a small fraction of the organic mass (Rogge et al., 1998; Saxena and Hildemann, 1996). Fourier Transform Infrared Spectrometry, like other techniques such as nuclear magnetic resonance (NMR) and aerosol mass spectrometry (AMS), does not identify individual molecular species but provides a functional-group based description of the physical and chemical properties of most of the organic fractions (Gilardoni et al., 2007; Maria et al., 2002, 2003). The organic functional group composition provides information about aerosol sources, aerosol aging, and air mass processing. The results presented here show that the contribution of oxidized functional groups to $\mathrm{OM}$ is generally larger in the urban plume.

The aerosol organic mass, here calculated as the sum of organic functional group masses, consists of carbon and hetero-atoms (i.e. oxygen, nitrogen, sulfur, hydrogen) that are bonded to the carbon skeleton of the organic compounds. The mass of organic aerosols composed mainly by aliphatic and aromatic hydrocarbons (like freshly emitted aerosols) is close to the sum of the carbon atom masses; the mass of organic aerosols characterized by oxidized molecules includes the contributions of oxygen, nitrogen, and sulfur atoms in addition to the carbon mass. The organic mass to organic carbon ratio $(\mathrm{OM} / \mathrm{OC})$ is an index of the contribution of hetero-atoms to the organic mass: chemically processed particles are expected to have higher $\mathrm{OM} / \mathrm{OC}$ ratio compared to freshly emitted and unprocessed aerosols. The OM/OC ratio also relates to the contribution of organic carbon (measured with evolved gas) to the total particulate mass. As such, the $\mathrm{OM} / \mathrm{OC}$ ratio together with the molar ratio of oxygenated functional groups relative to aliphatic $\mathrm{C}-\mathrm{H}$ groups are used here as metrics of both increases in hetero-atoms and oxidation which result from atmospheric processing (sometimes called aging) during the MIRAGE campaign at three sites.

\section{Methods and instrumentation}

\subsection{Sampling}

Ambient aerosol samples were collected during the MIRAGE campaign at three platforms: at the Mexico City Atmospheric Monitoring System building (SIMAT), at Altzomoni (Cortes Pass), and on board the NCAR C130 aircraft. The SIMAT building $\left(19^{\circ} 24^{\prime} 12^{\prime \prime} \mathrm{N}, 99^{\circ} 10^{\prime} 34^{\prime \prime} \mathrm{W}\right)$ is located in the Mexico City urban area, south of T0 (MCMA2006 supersite) (Molina et al., 2008). Industrialized areas, characterized by the presence of power plants and refineries, are located to the North; the dry lake bed of Texcoco Lake, a regional large source of dust, is located to the East. The Altzomoni sampling site $\left(19^{\circ} 07^{\prime} \mathrm{N}, 98^{\circ} 38^{\prime} \mathrm{W}\right)$ is approximately $60 \mathrm{~km}$ southeast of Mexico City on the saddle between Popocatepetl and Ixtaccihuatl volcanoes at an altitude of $4010 \mathrm{~m}$ (Baumgardner et al., 2009). Popocatepetl is an active volcano while Ixtaccihuatl is passively degassing and during March 2006 there were a large number of fires on the slope of this volcano (Crounse et al., 2009). Altzomoni is characterized by a diurnal transition from local to regional mixed layer air whose properties depend on prevailing winds and larger scale circulation. Anthropogenic emission sources that might affect the site are located in the Mexico City basin 

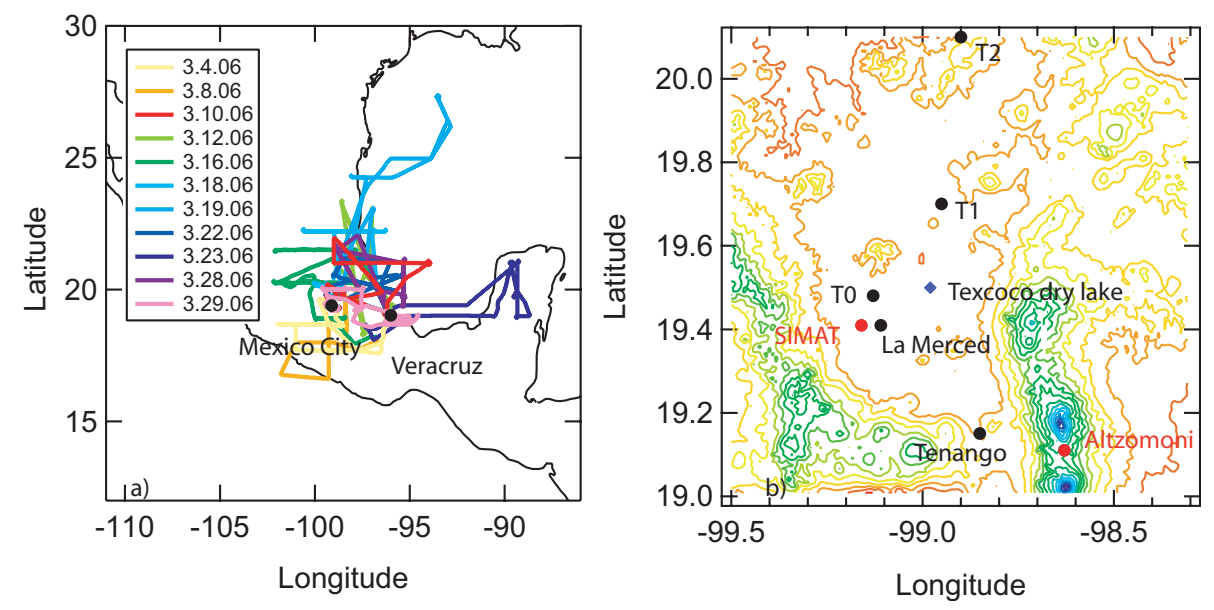

Fig. 1. NSF/NCAR C130 flight tracks colored as a function of flight date (a) and ground platform locations (b). Panel (b) reports the location of SIMAT and Altzomoni (red circles), other major sampling sites of MILAGRO (black circles), and lake Texcoco (blue diamond).

(to the northwest), Puebla (to the east), and Cuernavaca (to the southwest).

The C130 aircraft, whose operations were based in Veracruz, performed 12 research flights over Mexico and over the coast of the Gulf of Mexico. Figure 1 reports the C130 flight tracks, and the location of SIMAT and Altzomoni. The research flights were performed on 4 March (flight 1), 8 March (flight 2), 10 March (flight 3), 12 March (flight 4), 16 March (flight 5), 18 March (flight 6), 19 March (flight 7), 22 March (flight 8), 23 March (flight 9), 26 March (flight 10), 28 March (flight 11), and 29 March (flight 12). No filter samples were collected during flight 10 due to the shortness of the flight, and this flight is omitted from this analysis. During the MILAGRO campaign several urban and rural ground platforms were operated; Fig. 1b reports the sites that were used to investigate Mexico City outflow and that are mentioned in the present study for reference. The sampling campaign was performed during March 2006. Measurements at the three sites included a large set of online gas and particle characterization techniques.

Submicron aerosol samples were collected on $37 \mathrm{~mm}$ Teflon filters with a flow rate of $16.7 \mathrm{Lpm}$. At the ground platforms a 24-h sample was collected daily; in addition two 12-h samples were collected at Altzomoni and three 8-h samples at SIMAT. The shorter samples provide the primary information for this analysis; the simultaneous daily samples are used for quality control to assess organic components lost due to volatility. The 12-h Altzomoni samples were taken from approximately eleven in the morning until six in the evening and from six in the evening until eleven the next morning. These time periods were chosen to separate periods when the regional boundary layer was above and below the research site, respectively. On board the NCAR C130 samples were collected during constant altitude legs, for a sampling period that ranged in most of the cases between
$20 \mathrm{~min}$ and $1 \mathrm{~h}$. After collection, filters were put in sealed Petri dishes and stored at approximately $-4^{\circ} \mathrm{C}$ until analysis.

\subsubsection{Fourier Transform Infrared (FTIR) Spectrometry and X-Ray Fluorescence (XRF) measurements}

Teflon filters were analyzed by Fourier Transform Infrared Spectroscopy (FTIR) to characterize the composition of the organic aerosols (Gilardoni et al., 2007; Maria et al., 2002, 2003). FTIR measurements were performed with a Bruker Tensor 27 FTIR Spectrometer with a DTGS detector. FTIR spectra of the particulate matter deposited on the filters were acquired in transmission mode in the region $400-4000 \mathrm{~cm}^{-1}$ with a resolution of $4 \mathrm{~cm}^{-1}$; for each sample spectrum 128 scans were acquired. Filters were scanned before and after sampling, without sample extraction, and each aerosol spectrum was obtained by subtraction of the two absorption spectra to remove the Teflon interference. Ambient aerosol spectra were characterized by the broad signal of ammonium in the region $2800-3200 \mathrm{~cm}^{-1}$, which overlaps some of the organic functional group signals. To remove the ammonium interference, the reference absorption spectrum of ammonium sulfate, normalized to the ammonium signal at $3200 \mathrm{~cm}^{-1}$, was subtracted from each aerosol spectrum. The FTIR spectra were integrated using a guided algorithm (Russell et al., 2009).

The organic functional groups characterized during the project are reported in Table 1 along with the corresponding absorption wavenumbers and detection limits. The identified organic functional groups included non-acid organic hydroxyl C-OH group (including sugars, anhydrosugars, and polyols, herein indicated as alcohol group), aromatic $\mathrm{C}=\mathrm{C}$ $\mathrm{H}$ group, aliphatic unsaturated $\mathrm{C}=\mathrm{C}-\mathrm{H}$ group, aliphatic saturated $\mathrm{C}-\mathrm{C}-\mathrm{H}$ group, non-acid carbonyl $\mathrm{C}=\mathrm{O}$ group, carboxylic acid $\mathrm{COOH}$ group, and amine $\mathrm{NH}_{2}$ group. The 
Table 1. FTIR absorption signals used to identify and quantify organic functional group.

\begin{tabular}{lrrrrr}
\hline $\begin{array}{l}\text { Functional } \\
\text { group }\end{array}$ & $\begin{array}{r}\text { Frequency } \\
\mathrm{cm}^{-1}\end{array}$ & $\begin{array}{r}\text { Quantified Peak, } \\
\mathrm{cm}^{-1}\end{array}$ & $\begin{array}{r}\text { Absorptivity } \\
\mathrm{abs}^{-1} \mathrm{a}\end{array}$ & $\begin{array}{r}\text { Detection Limit } \\
\mu \mathrm{mol} \text { of bond }\end{array}$ & $\begin{array}{r}\mathrm{MW} \\
\mathrm{g} \mathrm{mol}^{-1 \mathrm{~b}}\end{array}$ \\
\hline $\begin{array}{l}\text { Aliphatic saturated } \\
\text { C-C-H }\end{array}$ & $\begin{array}{r}1450, \\
2800-3000\end{array}$ & $1850-2920$ & 0.6 & 0.079 & 7 \\
Aliphatic unsaturated C=C-H & $2900-3100$ & 2980 & 3.8 & 0.4 & 13 \\
Aromatic C=C-H & $3000-3100$ & 3050 & 8.7 & 1.2 & 13 \\
Non-acid carbonyl C=O & $1640-1850$ & 1720 & 0.067 & 0.010 & 28 \\
Carboxylic acid COOH & $1640-1850$ & 1720 & 10.02 & 0.013 & 45 \\
Alcohol C-OH & $3100-3500$ & 3350 & 0.057 & 0.011 & 23 \\
Organosulfate C-O-S & 876 & & & & \\
Amine $\mathrm{NH}_{2}$ & 3400,1625 & 1625 & 0.112 & 0.018 & 11 \\
\hline
\end{tabular}

\footnotetext{
a Absorptivity is the micromole of functional group per unit of peak area (in absorbance). The calibration of absorptivity is instrumentspecific.

${ }^{\mathrm{b}}$ Functional group molecular weight.
}

calibration coefficients of the organic groups were obtained by analysis of standard aerosol samples prepared with 1docosanol, anthracene, sodium benzoate, 1-docosene, alanine, citric acid, and adipic acid (Gilardoni et al., 2007; Liu et al., 2009). The absorbance of the measured functional groups is proportional to the number of moles and is independent of the mixture composition (Maria et al., 2002, 2003). The organic mass (OM) concentration was calculated by multiplying the molar functional group concentrations and the corresponding group molecular weights, then summing the contribution from the different groups. Organic carbon (OC) concentration was obtained by summing the carbon contributions from the different functional groups, which were equal to the functional group molar concentrations multiplied by an atomic mass of 12 . The algorithm used to calculate the $\mathrm{OM}$ and $\mathrm{OC}$ concentrations assumes that saturated carbon chains were present as $\mathrm{CH}_{2}$ units. The $\mathrm{OM}$ contribution of organic functional groups containing organosulfates (with C-O-S bonding) was below detection in all the samples. The uncertainty of functional group and organic mass concentration from calibration, peak integration, and sampling flow variability was between $5 \%$ and $21 \%$ for the range of samples reported here above detection limits (Russell, 2003; Maria et al., 2003; Gilardoni et al., 2007).

$\mathrm{X}$-Ray fluorescence measurements were performed on aerosol samples collected on Teflon filters after FTIR analysis. XRF measurements (Chester LabNet, Tigard, Oregon) quantified $\mathrm{Na}$ and heavier elements, including $\mathrm{S}, \mathrm{Cl}, \mathrm{Al}, \mathrm{Si}$, $\mathrm{K}, \mathrm{Zn}, \mathrm{Fe}, \mathrm{V}$ and Ni. The measurement uncertainties were on the order of $1-10 \mathrm{ng}$ per filter for all elements except $\mathrm{Na}$ for which the uncertainties were 10 times higher; the relative errors were lower than $10 \%$ for all elements including $\mathrm{Na}$.

\subsubsection{Aerosol Mass Spectrometry AMS}

Collocated Aerosol Mass Spectrometry (AMS) measurements (Canagaratna et al., 2007) were performed at Altzomoni and on the C130. At Altzomoni the quadrupole AMS (Q-AMS) instrument was operated with a time resolution of $5 \mathrm{~min}$ and collection efficiency of 0.5 (Jayne et al., 2000; Jimenez et al., 2003); lower transmission efficiency for particles at the upper end of the submicron range was observed (Zhang et al., 2002, 2004). The C130 AMS measurements were high resolution-time of flight (HR-ToF) spectra collected every $12 \mathrm{~s}$ (De Carlo et al., 2008, 2006), with collection efficiency of 0.5. The AMS instruments measure the chemical composition of the non-refractory fraction of submicron aerosol (Allan et al., 2003). The organic mass was calculated using the fragmentation table approach to remove the fragments from inorganic species (Allan et al., 2004).

AMS organic mass measurements were averaged over the sampling period corresponding to each FTIR sample. Figure 2 shows the comparison between FTIR and AMS organic mass concentration at Altzomoni and on the $\mathrm{C} 130$. Organic mass measurements from the AMS on the $\mathrm{C} 130$ were available during research flights $1-3$ and 9-12. The comparison included each measurement for which the AMS instrument was operated continuously during FTIR filter samples at constant altitude. The correlation coefficients $\left(r^{2}\right)$ between AMS and FTIR measurements were 0.53 at Altzomoni and 0.69 on the $\mathrm{C} 130$. The use of separate inlets on the $\mathrm{C} 130$ results in a size-distribution-dependent difference which may contribute to the scatter in the airborne measurements, particularly in samples with a substantial fraction of the submicron mass above $500 \mathrm{~nm}$. However, the small number of samples with comparable measurements for both instruments is likely to account for much of the weak correlation. The FTIR OM to AMS OM ratio was $0.80 \pm 0.06$ at Altzomoni. There were an insufficient number of points to obtain a reasonable line fit 
between the AMS and FTIR OM on the C130, but the available points typically had FTIR OM lower than AMS OM by a factor of 2. Lower OM concentrations measured by FTIR on the $\mathrm{C} 130$ might result in part from the short collection times and the low concentrations of some functional groups since many of the measurements were in the free troposphere. The magnitude of the potential underestimate of carboxylic acid and amine groups was calculated by estimating the upper bound of these components assuming concentrations below detection limit were equal to the detection limit. These upper bounds were smaller than the $\pm 20 \%$ uncertainty expected for OM (Russell, 2003). Desorption of volatile organic compounds during legs in and out of plume might explain, for longer sampling periods, the lower concentrations from filter measurements (FTIR) compared to on-line (AMS) measurements. The uncertainty of AMS measurements is dominated by uncertainty in the collection efficiency, conservatively considered to be $\pm 25 \%$ of the measured OM.

Figure $2 \mathrm{c}$ shows the comparison between FTIR OM/OC ratios and AMS OM/OC ratios for the $\mathrm{C} 130$ samples during periods characterized by overlapping FTIR and AMS measurements. The AMS OM/OC falls in the range of variability of FTIR values, calculated taking into account the uncertainty introduced by the low filter loadings. The FTIR values were typically $1.7 \pm 0.2$, which encompasses the values measured by AMS. The functional group composition, described by the pie charts, indicates that the larger variability of FTIR $\mathrm{OM} / \mathrm{OC}$ is associated with samples characterized by a larger uncertainty in the carboxylic acid group concentration. The upper bound of functional group composition is calculated assuming that the concentration values below detection limit were equal to the detection limit itself. This assumption leads to large variability for the $\mathrm{COOH}$ group due to its high absorbtivity (Table 1).

\section{Results and discussion}

\subsection{Composition of the organic mass}

The organic functional groups quantified by FTIR included alcohol C-OH, aromatic $\mathrm{C}=\mathrm{C}-\mathrm{H}$, aliphatic unsaturated $\mathrm{C}=\mathrm{C}$ $\mathrm{H}$, aliphatic saturated $\mathrm{C}-\mathrm{C}-\mathrm{H}$, non-acid carbonyl $\mathrm{C}=\mathrm{O}$, carboxylic acid $\mathrm{COOH}$, and amine $\mathrm{NH}_{2}$ groups. Organonitrates were investigated using the absorption signals at 1275 and $857 \mathrm{~cm}^{-1}$ (O'Brien et al., 1975a,b); these signals were below detection limit at all the three sites during the entire campaign. Organic sulfates, which can be identified by the absorption of infrared radiation associated with the bending of the carbon-oxygen-sulfur functional group, were found to be below detection limit for all samples, consistent with the lack of fragments containing both $\mathrm{C}$ and $\mathrm{S}$ from high-resolution AMS at T0 (Aiken et al., 2008). This finding was consistent with the comparison of the C130 samples for sulfate concentration from AMS and the XRF elemental sulfur. The
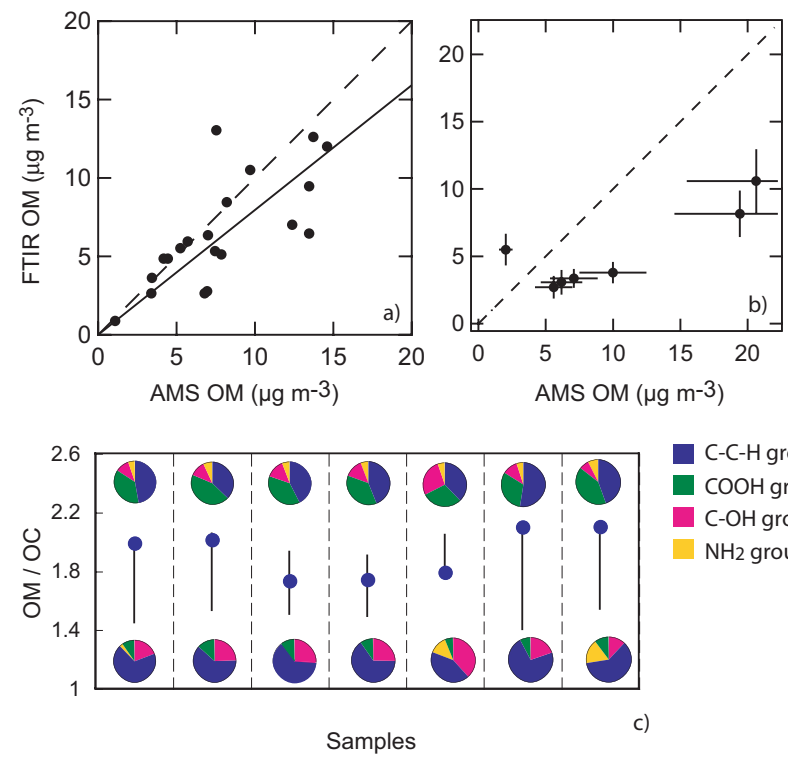

C-C-H group - $\mathrm{COOH}$ group C-OH group $\mathrm{NH}_{2}$ group

Fig. 2. Comparison of FTIR OM and AMS average OM (a) at Altzomoni and (b) on the C130; the solid lines correspond to linear fit of experimental data while the dash line shows the 1:1 ratio. Error bars in panel a are omitted for simplicity; line fit in panel $b$ is not reported because of the limited number of datapoints. Panel (c): comparison of FTIR OM/OC range (black lines) and AMS OM/OC (blue circles) on the $\mathrm{C} 130$. Pie charts indicate the organic functional group composition of the OM/OC lower and upper bounds: aliphatic saturated $\mathrm{C}-\mathrm{C}-\mathrm{H}$ in blue, amine $\mathrm{NH}_{2}$ in yellow, carboxylic acid $\mathrm{COOH}$ in green, and alcohol $\mathrm{C}-\mathrm{OH}$ in pink.

two sets of measurements correlated with a slope of 1.07 and at a confidence level larger than $99.95 \%$ (data not shown). The nearly 1:1 ratio is consistent with the low concentrations of organosulfate reported by FTIR, although this observation is not sufficient for an independent confirmation. The lack of organosulfate groups also is consistent with the complete neutralization of the anions (sulfates and nitrates) by ammonium observed, within the error of measurements (De Carlo et al., 2008).

The average $\mathrm{OM}$ concentration at standard conditions (273.15 $\mathrm{K}$ and $1 \mathrm{~atm}$ ) was $9.9 \mu \mathrm{g} \mathrm{m}^{-3}$ at SIMAT, $6.6 \mu \mathrm{g} \mathrm{m}^{-3}$ at Altzomoni, and $5.7 \mu \mathrm{g} \mathrm{m}^{-3}$ on the $\mathrm{C} 130$. The average OC concentration at SIMAT was $5.3 \mu \mathrm{g} \mathrm{m}^{-3}$, comparable to the OC mean concentration measured by thermo-optical method at a peripheral site in Mexico City (T1) (Doran et al., 2007; Querol et al., 2008; Stone et al., 2008) but lower than the value reported by Chow et al. (2002) close to the SIMAT site during March 1997 and lower than the values reported at CENICA in 2003 and at T0 in 2006 (Aiken et al., 2008; Salcedo et al., 2006; Stone et al., 2008). Figure 3 shows the campaign average contribution of each functional group to the OM on the three platforms. For simplicity aliphatic unsaturated and aromatic groups, whose contribution was usually lower than $1 \%$ and often below detection limit, are not 

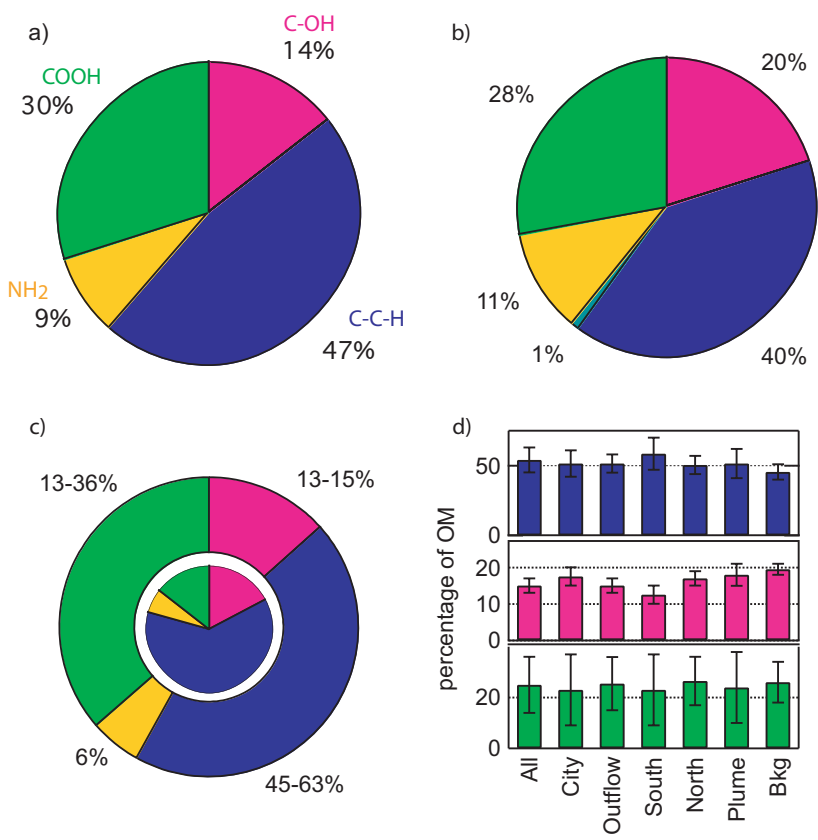

Fig. 3. Project average composition of organic mass for (a) Mexico City, (b) Altzomoni, and (c) C130 (the inner chart corresponds to the actual concentration and the outer chart corresponds to the assumption that concentrations below detection limit are equal to detection limit). The charts show aliphatic saturated $\mathrm{C}-\mathrm{C}-\mathrm{H}$ in blue, non-acid carbonyl $\mathrm{C}=\mathrm{O}$ in cyan (below $1 \%$ in panel a and c), amine $\mathrm{NH}_{2}$ in yellow, carboxylic acid $\mathrm{COOH}$ in green, and alcohol $\mathrm{C}-\mathrm{OH}$ in pink. Panel (d) alcohol (pink) and carboxylic acid (green) contribution to $\mathrm{OM}$ on the $\mathrm{C} 130$ as a function of sampling location: over the urban area (City), outside the urban area (Outflow), North of the city (North), South of the city (South), inside the urban plume (Plume), and outside the plume (Bkg).

reported. The average composition reported for the $\mathrm{C} 130$ is obtained from the analysis of samples with collection time longer than $10 \mathrm{~min}$ and shorter than $2 \mathrm{~h}$, to assure low noise level and reduce potential artifacts due to loss of volatile compounds in longer sampling periods. The average compositions at the two ground platforms were similar, suggesting that when the winds are from the North or Northwest the high altitude site is affected by MCMA air masses (Baumgardner et al., 2009). At the ground sites, the largest contribution to OM came from aliphatic saturated C-C-H and carboxylic acid $\mathrm{COOH}$ group, which together represented more than $60 \%$ of the OM. The average contribution of alcohol $\mathrm{C}-\mathrm{OH}$ group varied, averaging $14 \%$ at SIMAT, $13-15 \%$ on the $\mathrm{C} 130$, and $20 \%$ at Altzomoni; amine $\mathrm{NH}_{2}$ group represented about $10 \%$ of the organic mass both at SIMAT and Altzomoni, and $6 \%$ on the $\mathrm{C} 130$. The presence of amine at SIMAT is consistent with the results of Moffet et al. (2008) at T0 (urban site) where the nitrogen-organic carbon particles represent about $3-5 \%$ of the submicron particle number.
Figure 3d illustrates the properties of Mexico City outflow showing the percentage contribution of aliphatic saturated, carboxylic acid, and alcohol groups to OM, as a function of location relative to the Mexico City metropolitan area (MCMA). C130 city samples were collected at about $1000 \mathrm{~m}$ above ground level (a.g.l.) during the afternoon, and thus inside the mixing layer, with altitudes reaching $2000 \mathrm{~m}$ a.g.l. and frequently extending to $4000 \mathrm{~m}$ a.g.l. (Shaw et al., 2007). The C130 samples collected outside the city were often in the free troposphere. The comparison between city and outflow samples shows that the contribution of carboxylic acid $\mathrm{COOH}$, aliphatic saturated $\mathrm{C}-\mathrm{C}-\mathrm{H}$, and alcohol $\mathrm{C}-\mathrm{OH}$ group are within the variability bars in all sectors. The terrain structure around Mexico City is characterized by mountains to the east, south and west of the metropoli$\tan$ area that reach on average $1000 \mathrm{~m}$ above the basin, with two volcanoes at the Southeast that reach over $5000 \mathrm{~m}$ a.g.l.; the terrain features, together with the prevailing meteorological conditions during the MILAGRO experiment, favored the transport of Mexico City air masses towards the North. The comparison between samples collected north and south of the urban area (Fig. 3d) shows a smaller contribution of saturated aliphatic groups and a larger contribution of alcohol groups to the North, where the most frequent direction of the urban outflow was located (Doran et al., 2007).

Tie et al. (2009) use meteorological data and CO measurements to identify the periods when the $\mathrm{C} 130$ flights intercepted the urban plume and background air masses. Flexpart retroplume trajectories are used to identify urban plume and background samples among filters collected during research flight $2,3,6,8$, and 11 . These flights were chosen because they included Mexico City overpasses, sampling of urban plume at different distance form the source, and collection of background samples. During flight 6 the aircraft intercepted the urban plume only during the last part of the flight, and during flight 11 the flight track was mostly located upwind of the plume. Samples collected during the first part of flight 6 and during fight 11 represent background aerosol. Samples collected during the central part of flight 2 and 8 and the last part of flight 3 are representative of the urban plume. Figure $3 \mathrm{~d}$ compares functional group compositions of plume and background samples. On average background aerosol masses showed a slightly larger contribution of alcohol groups and a smaller contribution of aliphatic saturated groups; the differences are within the variability ranges because of the variability of aerosol composition with plume age.

The time series of functional group composition are reported in Fig. 4, together with wind speed, relative humidity, and mass time series. Measurements of particle mass at SIMAT were collected for $\mathrm{PM}_{2.5}$ measured by attenuation of beta radiation. For simplicity aliphatic unsaturated, aromatic groups, and non-acid carbonyl, whose contribution was usually lower than $1 \%$, are not reported. Meteorological and mass measurements reported for the SIMAT 


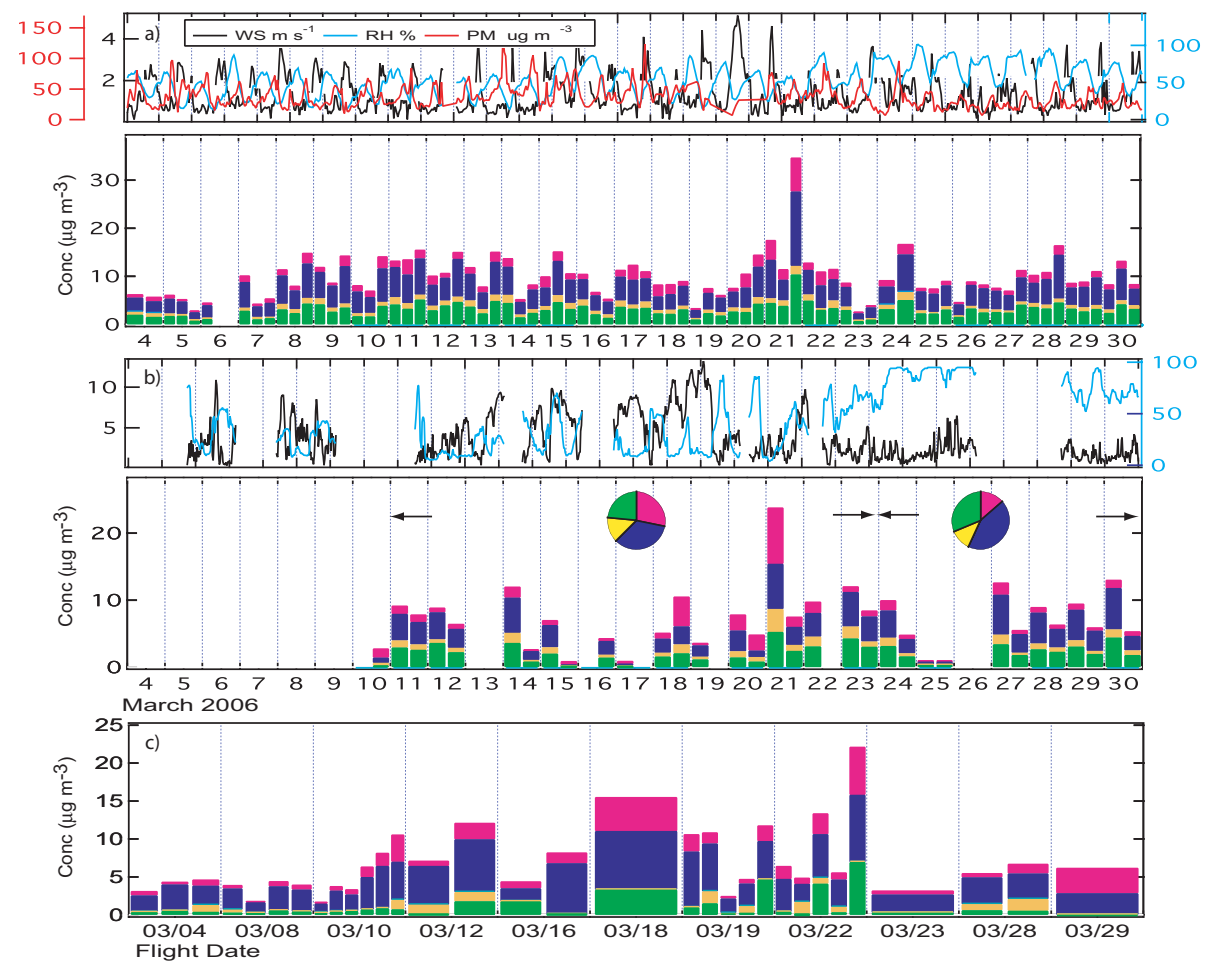

Fig. 4. Time series of the measured functional group composition with temperature (in black) relative humidity (in blue), and mass (in red) at (a) Mexico City and (b) Altzomoni; panel (c) reports functional group composition of C130 samples characterized by collection period longer than $10 \mathrm{~min}$ and shorter than $2 \mathrm{~h}$. The charts show aliphatic saturated $\mathrm{C}-\mathrm{C}-\mathrm{H}$ in blue, amine $\mathrm{NH}_{2}$ in yellow, carboxylic acid $\mathrm{COOH}$ in green, and alcohol $\mathrm{C}-\mathrm{OH}$ in pink.

site were recorded by the Ambient Air Monitoring Network (Red Automatica de Monitoreo Atmosferico, RAMA) at the Merced station. The organic mass concentration ranged between 3 and $35 \mu \mathrm{g} \mathrm{m}^{-3}$ at SIMAT, 1 and $24 \mu \mathrm{g} \mathrm{m}^{-3}$ at Altzomoni, and 2 and $22 \mu \mathrm{g} \mathrm{m}^{-3}$ during the C130 flights. At Altzomoni higher OM values were observed during daytime compared to nighttime: the average OM concentrations were $9.4 \mu \mathrm{g} \mathrm{m}^{-3}$ and $5.6 \mu \mathrm{g} \mathrm{m}^{-3}$, respectively. Figure 4 shows similar OM temporal trends for the two ground sites. At SIMAT lower OM concentrations were observed during episodes characterized by wind speed higher than $2 \mathrm{~m} \mathrm{~s}^{-1}$ or relative humidity close to $100 \%$, indicating that organic mass concentration was modulated by removal mechanisms, i.e. transport and wet deposition. The highest concentrations on 20 and 21 March are likely related to intense biomass burning plumes and smoke from nearby forest fires (Aiken et al., 2009). At Altzomoni the peaks of OM concentration observed on 14, 21, and 23 March may be related to the presence of cold surge episodes that favored the transport of air pollutants from the city basin towards the South (de Foy et al., 2008). At Altzomoni the OM concentration started decreasing on 23 March (in association with rain and snow events) and increased again after 27 March, with the reduction of wind speed and relative humidity.
Aliphatic saturated C-C-H and carboxylic acid $\mathrm{COOH}$ groups represented the largest fraction of the organic mass throughout the sampling campaign at the ground sites. At SIMAT the average composition of the OM was roughly constant during the entire month; at Altzomoni a larger contribution of alcohol C-OH was observed during the driest period of the campaign, before 24 March, when alcohol C-OH fraction reached peaks of $40 \%$. The pie charts in Fig. $4 \mathrm{~b}$ shows the average functional group composition at Altzomoni before (dry period) and after (wet period) $24 \mathrm{March}$; the average contribution of alcohol $\mathrm{C}-\mathrm{OH}$ group to $\mathrm{OM}$ during the dry and wet period was $25 \%$ and $11 \%$, respectively. Alcohol $\mathrm{C}-\mathrm{OH}$ group can be found in ambient aerosol as alcohols, polyols, and sugars (Graham et al., 2002; Simoneit et al., 2004a,b). Relevant sources of sugars, anhydrosugars, and sugar alcohols are biogenic emissions and biomass burning (Graham et al., 2002; Mayol-Bracero et al., 2002). Levoglucosan, an anhydro-sugar widely used as a tracer of biomass burning, might represent more than $10 \%$ of the OC produced by wood combustion (Fine et al., 2002; Simpson et al., 2007). The importance of biomass combustion as source of alcohol C-OH group is further supported by the high correlation at SIMAT between alcohol C-OH group and $\mathrm{K}$ (Liu et al., 2009), an additional tracer of biomass burning.The correlation coefficient of $\mathrm{K}$ and alcohol C-OH group $\left(r^{2}=0.61\right)$ is 
Table 2. Mean, minimum, and maximum elemental concentrations $\left(\mathrm{ng} \mathrm{m}^{-3}\right)$ at SIMAT site.

\begin{tabular}{lrrr}
\hline Element & Mean & Minimum & Maximum \\
\hline $\mathrm{S}$ & 950 & 240 & 3400 \\
$\mathrm{~K}$ & 170 & 52 & 460 \\
$\mathrm{Si}$ & 130 & 16 & 1000 \\
$\mathrm{Ca}$ & 110 & 1 & 850 \\
$\mathrm{Na}$ & 90 & 10 & 0.49 \\
$\mathrm{Fe}$ & 92 & 2 & 528 \\
$\mathrm{Al}$ & 51 & 10 & 550 \\
$\mathrm{Cl}$ & 41 & 7.4 & 200 \\
$\mathrm{Zn}$ & 36 & 3.9 & 190 \\
$\mathrm{As}$ & 12 & 1.5 & 45 \\
$\mathrm{Sn}$ & 6.6 & 2.0 & 24 \\
$\mathrm{Cu}$ & 9.6 & 1.2 & 62 \\
$\mathrm{~V}$ & 7.8 & 0.7 & 11 \\
$\mathrm{Br}$ & 6.3 & 1.3 & 20 \\
$\mathrm{Mn}$ & 4.3 & 0.88 & 25 \\
$\mathrm{Ti}$ & 4.5 & 1.1 & 34 \\
$\mathrm{P}$ & 4.8 & 3.4 & 6.2 \\
$\mathrm{Ni}$ & 1.6 & 0.49 & 20 \\
\hline
\end{tabular}

lower than correlation of soil elements to each other. This lower correlation is expected because of the variability in the emission factors for biomass burning molecular markers, depending on combustion conditions, biomass type (i.e. grass or wood), and biomass composition (Fine et al., 2002; Jordan and Seen, 2005). The decrease of alcohol C-OH contribution during the wet period can be linked to the lower intensity and frequency of fires in the regions, as determined by satellite measurements (Fast et al., 2007; Aiken et al., 2009). On the $\mathrm{C} 130$ the organic mass was on average dominated by aliphatic saturated C-C-H group; carboxylic acid $\mathrm{COOH}$ group was an important fraction of the organic mass in samples collected north of the city basin during research flights 5 (16 March), 7 (19 March), and 8 (22 March), when its contribution was larger than $30 \%$ of the OM.

\subsection{Elemental composition of Mexico City urban aerosol}

At SIMAT S, Na, K, Si and Ca were the most abundant elements measured by XRF (Table 2). The concentrations for submicron markers, including dust, were lower than reported for $\mathrm{PM}_{2.5}$ Mexico City aerosols (Chow et al., 2002; Miranda et al., 1996, 2004; Querol et al., 2008) but similar to particles between 0.34 and $1.15 \mu \mathrm{m}$ during MCMA-2003 (Johnson et al., 2006), consistent with the fact that crustal elements are mainly associated with particles larger than $1 \mu \mathrm{m}$. As and $\mathrm{Na}$ were more than 4 times lower during MCMA 2003 than here.
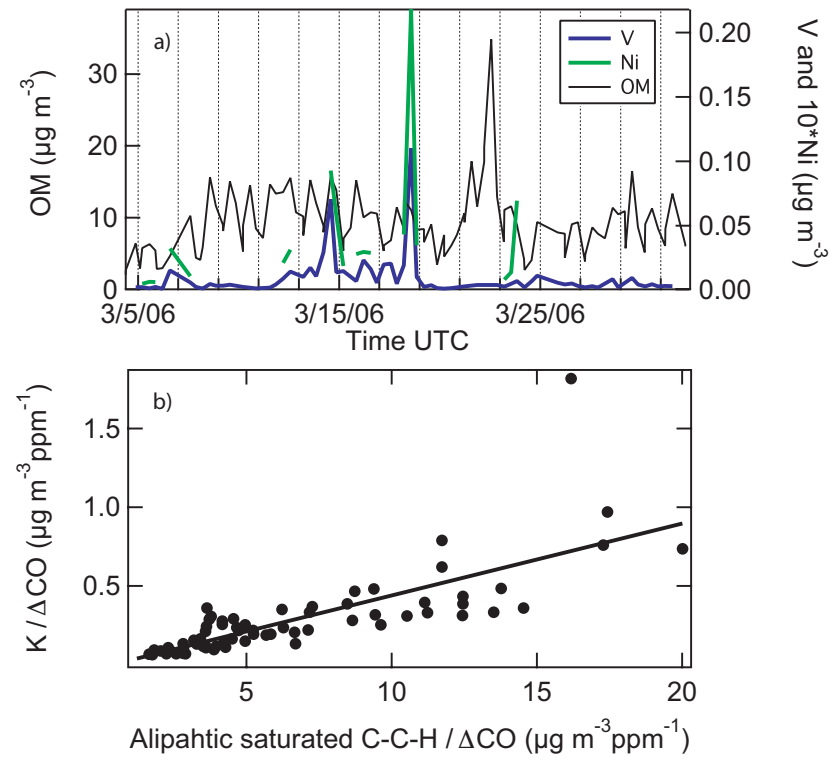

Fig. 5. Panel (a): time series for vanadium (blue), nickel (green), and organic mass OM (black) concentrations at SIMAT. Panel (b): scatter plot of $\mathrm{OM}$ and potassium concentrations corrected for dilution.

Figure 5a shows that on 14 and 18 March during peaks in $\mathrm{S}$ concentration, the $\mathrm{V}$ and $\mathrm{Ni}$ time series also show two maxima suggesting that $\mathrm{V}, \mathrm{Ni}$, and $\mathrm{S}$ are co-emitted by a common fuel-burning source. Vanadium and nickel are commonly detected in aerosol produced by fossil fuel combustion (Moffet et al., 2008). The large average $\mathrm{SO}_{2}$ flux emission calculated during MCMA 2006 for the Tula industrial complex (Rivera et al., 2009) indicates that the region north of Mexico City is a strong source of industrial pollution. The highest $\mathrm{V}$ and $\mathrm{Ni}$ concentrations were observed when the wind direction was from the North. Fast et al. (2007) show that 14 March and 18 March were characterized by transport of air masses from north and northeast towards south into the basin. The average $[\mathrm{V}] /[\mathrm{Ni}]$ ratio was $5.1\left(r^{2}=0.86\right)$, in accordance with emission ratios reported for fuel oil burning (Kowalczyk et al., 1982; Maenhaut and Cafmeyer, 1987). A similar episode characterized by the same $[\mathrm{V}] /[\mathrm{Ni}]$ ratio and transport from the North was observed during MCMA-2003, indicating a strong anthropogenic, rather than volcanic, source of sulfate (Johnson et al., 2006). We did not observe a correlation between $\mathrm{V}$ and the organic functional group concentrations observed in Mexico City at SIMAT (Liu et al., 2009). The temporal trend of OM and V concentrations at SIMAT, reported in Fig. 5a, indicates that fuel oil burning (associated with industrial activity and energy production) was not one of the major sources of organic mass in the urban area.

A strong correlation was observed among time series of $\mathrm{Si}, \mathrm{Ca}$ and $\mathrm{Al}$, commonly attributed to soil sources (Miranda et al., 2004, 1994). Si, Ca and K concentrations showed a positive correlation with $\mathrm{Al}$ concentrations (Fig. 6). The 

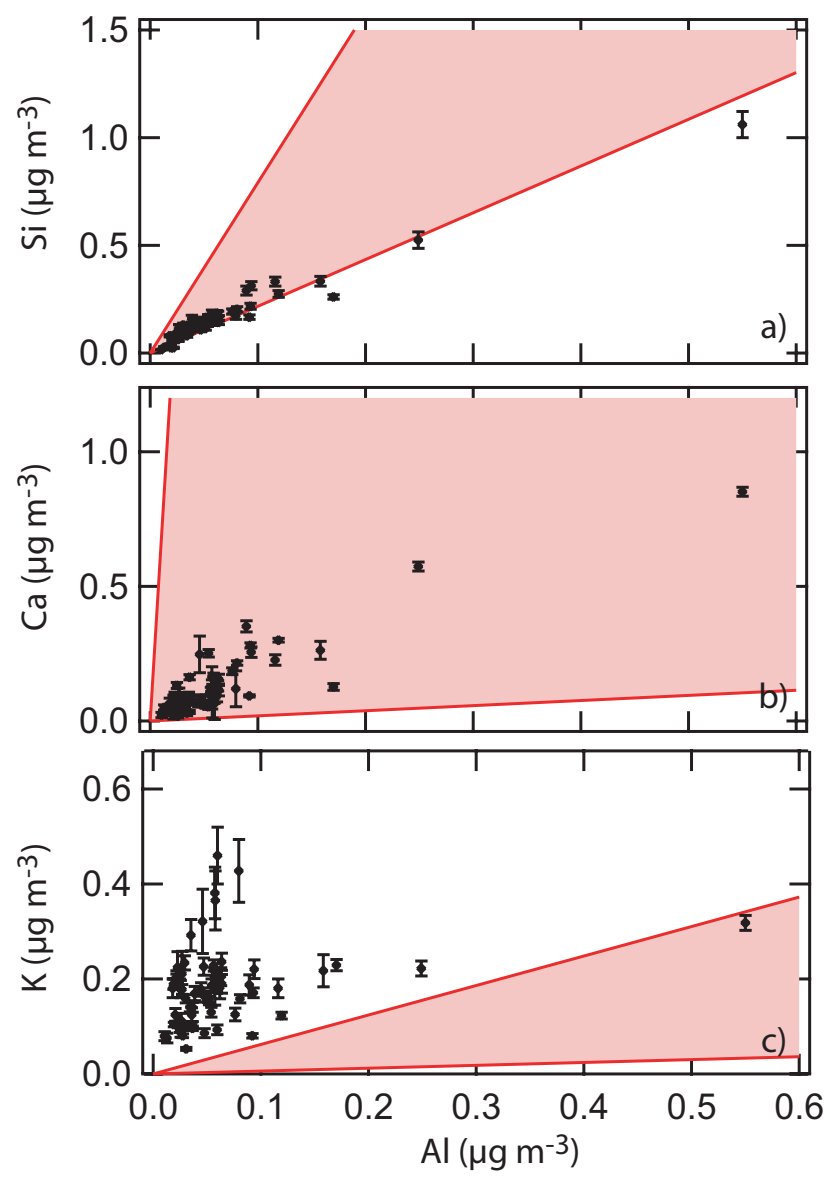

Fig. 6. Concentration of (a) silicon, (b) calcium, and (c) potassium relative to aluminum, in Mexico City; shaded areas correspond to the expected ratio according to Vega et al. (2001).

linear correlation coefficient $r^{2}$ was 0.95 for $\mathrm{Si} / \mathrm{Al}$ and 0.80 for $\mathrm{Ca} / \mathrm{Al}$, while a poor linear correlation was observed between $\mathrm{K}$ and $\mathrm{Al}\left(r^{2}=0.05\right)$. Figure 6 also shows the range of variability for the ratios between each metal and $\mathrm{Al} \mathrm{ob-}$ served for fugitive dust emitters in Mexico City (Vega et al., 2001). Si/Al and $\mathrm{Ca} / \mathrm{Al}$ ratios measured during this study (2.3 and 1.9, respectively) were close to the ratios reported by Vega et al. (2001) for paved and unpaved roads, soil, and asphalt. $\mathrm{K}$ concentration was higher than the value expected for soils, indicating that road and soil dust were not the exclusive sources of this element.

Concentrations of potassium and aliphatic saturated C$\mathrm{C}-\mathrm{H}$ were divided by carbon monoxide concentration (CO) to correct for dilution. A strong correlation was observed (Fig. 5b), at a confidence level larger than $99.95 \%\left(r^{2}=0.72\right)$. Similarly a strong correlation between potassium and the sum of organic and elemental carbon was observed at the urban sites (CENICA and T0) and the suburban site T1 as reported by Querol et al. (2008), although these authors also reported a higher correlation between $\mathrm{K}$ and $\mathrm{Al}$. The correlation between $\mathrm{K}$ and aliphatic $\mathrm{C}-\mathrm{C}-\mathrm{H}$ group observed at
SIMAT indicates biomass burning as a possible common source for both components (Andreae and Merlet, 2001; Duan et al., 2004). Higher K concentrations were observed during the first part of the sampling campaign, when numerous fires were observed throughout Mexico with a large number located near the urban area (Fast et al., 2007). Figure 7 shows several fires near the SIMAT site identified by MODIS (Moderate Resolution Imaging Spectroradiometer) during the days with the highest $\mathrm{K}$ concentrations. In addition to forest fires (Yokelson et al., 2007), potential sources of biomass burning aerosol observed in the urban area were cooking, incineration, and refuse burning (Moffet et al., 2008).

Biomass burning aerosols are characterized by elevated $\mathrm{OC}$ and $\mathrm{K}$ content. In order to investigate the contribution of biomass burning to the organic aerosol we first estimated $\mathrm{K}$ from non-soil sources using:

$[\mathrm{K}]_{\text {non }- \text { soil }}=[\mathrm{K}]-[\mathrm{Al}] \mathrm{R}_{\text {soil }}$

where $[\mathrm{K}]_{\text {non-soil }}$ is the non-soil $\mathrm{K}$ concentration, $[\mathrm{K}]$ and [Al] are $\mathrm{K}$ and $\mathrm{Al}$ concentrations, and $\mathrm{R}_{\text {soil }}$ is the $\mathrm{K}$ to $\mathrm{Al}$ ratio in Mexico City dust emitters (Vega et al., 2001). The minimum and maximum non-soil $\mathrm{K}$ concentrations were calculated using the maximum and minimum $\mathrm{R}_{\text {soil }}$ reported by Vega et al. (2001) (0.62 for the dry lake and 0.06 for agricultural soil). Figure $7 \mathrm{f}$ shows that $\mathrm{OC}$ co-varied with the concentration of non-soil K, with a confidence level larger than $99.9 \%$. The average $[\mathrm{K}] / \mathrm{OC}$ ratio was 0.03 , in agreement with the average ratio observed for $\mathrm{PM}_{2.5}$ in $\mathrm{T} 0(0.02)$ by Querol et al. (2008) and with emission factors reported by Andreae and Merlet (2001) and by Watson and Chow (2001) for agricultural residue burning (0.04). The ratios here were comparable to the $[\mathrm{K}] / \mathrm{OC}$ ratios observed for biomass burning episodes of 0.04 for $\mathrm{PM}_{2.5}$ in Seoul (Kang et al., 2006), 0.01-0.02 for $\mathrm{PM}_{10}$ in the French Alps (Aymoz et al., 2007), but lower than 0.19-0.20 for total suspended particles (TSP) in Beijing (Duan et al., 2004).

The intercepts of the linear fits reported in Fig. $7 \mathrm{f}$ are statistically larger than zero $\left(2.8 \pm 0.5\right.$ and $3.3 \pm 0.4 \mu \mathrm{g} \mathrm{m}^{-3}$ of $\mathrm{OC})$, consistent with the presence of sources of OC not related to $\mathrm{K}$. We estimated the contribution of biomass burning to $\mathrm{OC}$ as the difference between the $\mathrm{OC}$ concentration and the average non-biomass burning OC. On average this contribution ranged between 33\% and 39\% for the lowest and highest estimates of soil $\mathrm{K}$, respectively. The OC associated with $\mathrm{K}$ calculated here includes soil and biomass burning emissions, in addition to urban sources that are somewhat different from more developed urban areas, namely open air grilling and cooking (Moffet et al., 2008). For this reason, the high contribution of $\mathrm{K}$ to the organic carbon is expected to be higher than the results of Stone et al. (2008), who reported a contribution of biomass burning ranging between $5-26 \%$ at $\mathrm{T} 0$ and $7-39 \%$ at $\mathrm{T} 1$, in particles smaller than $2.5 \mu \mathrm{m}$. Similarly single particle analysis of the upper end of the accumulation mode at T0 assigned $40 \%$ of particle number to biomass burning (Moffet et al., 2008) and AMS 

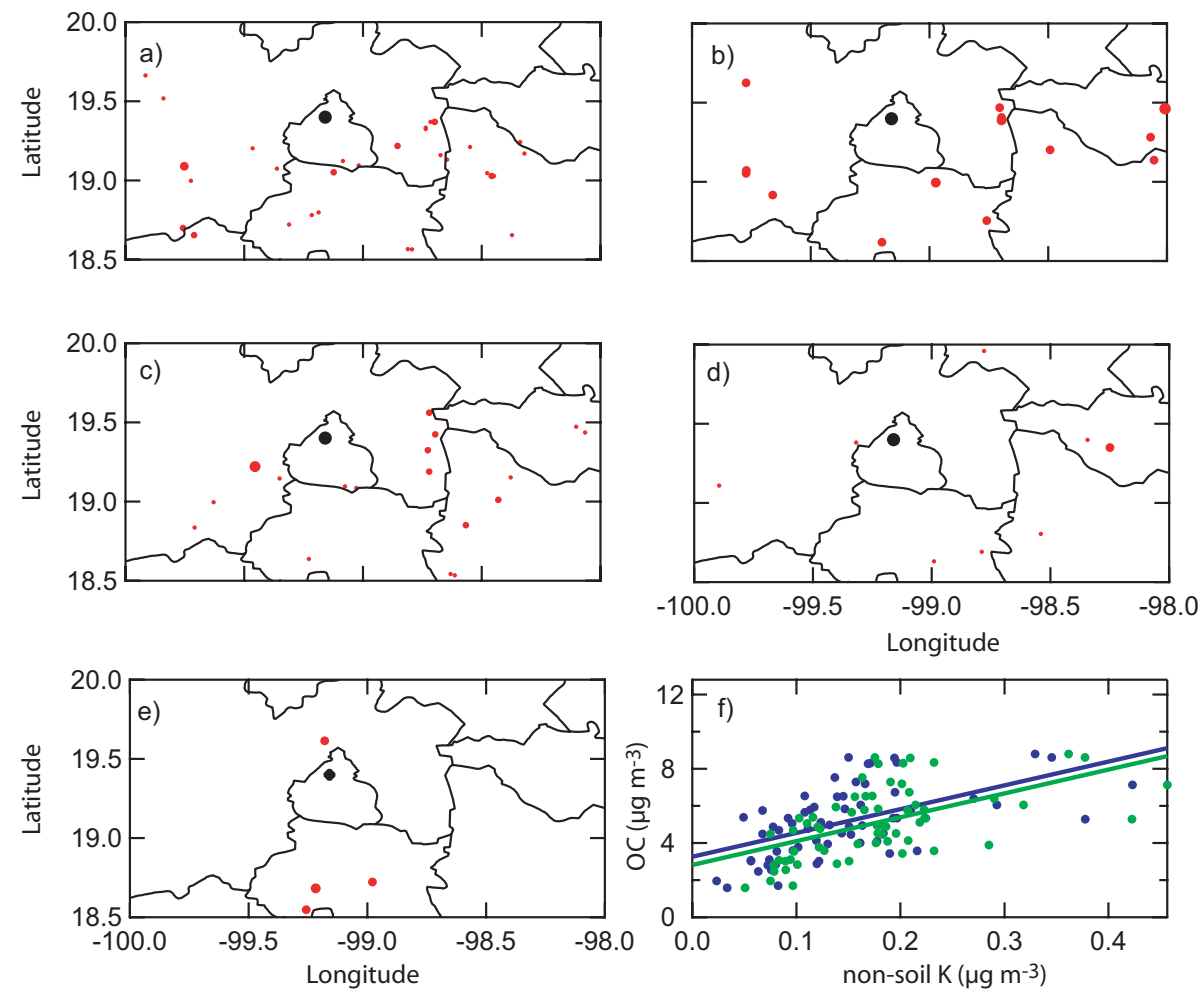

Fig. 7. (a-e): SIMAT site (black) and fire locations (red) according to Terra and Aqua satellite images on days with high potassium concentration: (a) 8 March, (b) 12-13 March, (c) 17-18 March, (d) 22 March, and (e) 28 March; dot size is proportional to the fire size. Panel (f) reports OC concentration as a function of non-soil potassium concentration (lower bound in blue and upper bound in green).

measurements apportioned $15-23 \%$ of the $\mathrm{OM}$ in submicron aerosol to biomass burning fires (which may not include nontraditional biomass sources) (Aiken et al., 2009). The contribution of meat cooking and refuse burning, which might have strong influence on a local scale, could justify the difference among the sites.

\section{$3.3 \quad \mathrm{OM} / \mathrm{OC}$ ratios}

The organic mass to organic carbon ratio $(\mathrm{OM} / \mathrm{OC})$ is a measure of the molecular composition of the organic fraction of aerosols. Aerosols characterized by high concentrations of oxygen, nitrogen and sulfur compounds exhibit high OM/OC values; organic particles dominated by aliphatic and aromatic hydrocarbons show low OM/OC ratios (Maria et al., 2003; Russell, 2003; Turpin and Lim, 2001). Experimental measurements of OM/OC ratios are still scarce. Kiss et al. (2002) calculated an OM/OC ratio of 1.9-2 for water-soluble organic matter at a rural site in Hungary. The average OM/OC ratio for dichloromethane and acetone extracts reported for IMPROVE site aerosols was 1.92 (El-Zanan et al., 2005). FTIR measures the OM/OC ratio for polar and non-polar organic fractions without the need for solvent extraction. During the ICARTT campaign we measured OM/OC of 1.4 for recently emitted particles from coal burning power plants in
Ohio, and 1.6 for or East coast outflow measured in the Gulf of Maine (Gilardoni et al., 2007).

OM/OC ratios calculated from AMS measurements (Aiken et al., 2007) during MIRAGE ranged between 1.61.8 in the urban area and 1.8-2.1 on the C130 (Aiken et al., 2008). Figure 8a reports OM/OC ratios for the three MILAGRO sampling platforms; similar average OM/OC ratios were observed at SIMAT and at Altzomoni, 1.8 and 2.0, respectively. The lower variability observed at SIMAT compared to the other sites (5 and 95 percentile equal to 1.7 and 2.1) reflects a more uniform composition of organic aerosol during the campaign. The geographical features of the Mexico City Basin, i.e. high altitude and subtropical latitude with the consequent high solar radiation, promote the formation of photochemical pollutants leading to a highly oxidized aerosol and thus high $\mathrm{OM} / \mathrm{OC}$ ratio.

Figure $8 \mathrm{~b}$ shows the $\mathrm{OM} / \mathrm{OC}$ ratio at Altzomoni, as a function of mixing-layer height (MLH) and wind direction. Mixing-layer height was determined from ceilometer measurements according to Emeis et al. (2007) at Tenango del Aire $\left(19^{\circ} 10 \mathrm{~N}, 98^{\circ} 51 \mathrm{~W}\right)$, a rural background site located five kilometers to the west of Altzomoni at $2377 \mathrm{~m}$ a.s.l. (see Fig. 1b). Altzomoni was a high altitude site and the daily modulation of the MLH allowed air masses affected by local sources from the surrounding valleys to reach the sampling 
location; on the contrary, when the MLH was lower than the site altitude, free tropospheric air masses were sampled. The samples characterized by the highest $\mathrm{OM} / \mathrm{OC}$ in Fig. $8 \mathrm{~b}$ are located at the top corner of the panel, indicating the sampling site was inside the boundary layer. During the corresponding sampling periods, prevailing wind direction was from the North and the Northwest (i.e. Mexico City direction) as indicated by the blue/purple color of the markers. The highest OM/OC values at Altzomoni were observed on $10,18,20,21$, and 22 March, during the winds from the Northwest. In general, the high OM/OC indicates Altzomoni was reached by oxidized particles; the air masses reaching the site from Mexico City basin were even more oxidized than the air masses sampled when the site was outside the mixing-layer.

The average $\mathrm{OM} / \mathrm{OC}$ ratio on the $\mathrm{C} 130$ was $1.6-1.8$. Figure $8 \mathrm{c}$ and $\mathrm{d}$ displays the flight track segments of $\mathrm{C} 130$ with the corresponding $\mathrm{OM} / \mathrm{OC}$ ratio for samples collected in plume and out of plume. An OM/OC ratio close to 2 indicates a large contribution of ketones, aldehydes, carboxylic acids and alcohols (Russell, 2003), which is consistent with the occasionally high concentration of carboxylic acid $\mathrm{COOH}$ group observed on the C130. Samples collected when the C130 was north or northeast of the Mexico City basin exhibited the highest $\mathrm{OM} / \mathrm{OC}$, close to the values observed at SIMAT (the urban site). The chemical properties of aerosols sampled by the aircraft confirmed North-Northeast was the most common direction of the basin outflow during the March 2006 campaign, as also indicated by basin wind transport analysis (de Foy et al., 2008; Doran et al., 2007), gas phase analysis of aging tracers (Kleinman et al., 2008), and Flexpart model results. Flexpart retro-plumes show that more than $70 \%$ of the $\mathrm{C} 130 \mathrm{OM} / \mathrm{OC}$ measurements correspond to south-to-north transport conditions. The flight tracks that intercepted the urban plume are reported in Fig. $8 \mathrm{c}$ while those that sampled background air masses are reported in Fig. 8d. Background air masses exhibit OM/OC values larger than those measured close to the urban area but smaller than values observed for urban plume far north of the city. The increase of $\mathrm{OM} / \mathrm{OC}$ for plume samples is likely due to different aging and processing of sampled air masses.

\subsection{Carboxylic acid group and aliphatic saturated C-C-H group}

The molar ratio of $\mathrm{C}=\mathrm{O}$ (carboxylic acid and non-acid carbonyl groups) to aliphatic $\mathrm{C}-\mathrm{H}$ group defines the increase in oxygenated organic components relative to the aliphatic hydrocarbon components. Since physical properties of compounds with more oxidized and fewer hydrocarbon groups are expected to be associated with more water soluble compounds, non-acid $\mathrm{C}=\mathrm{O}$ plus $\mathrm{COOH}$ to aliphatic $\mathrm{C}-\mathrm{H}$ molar ratio might help to understand the polarity and therefore the hygroscopic properties of aerosol particles.
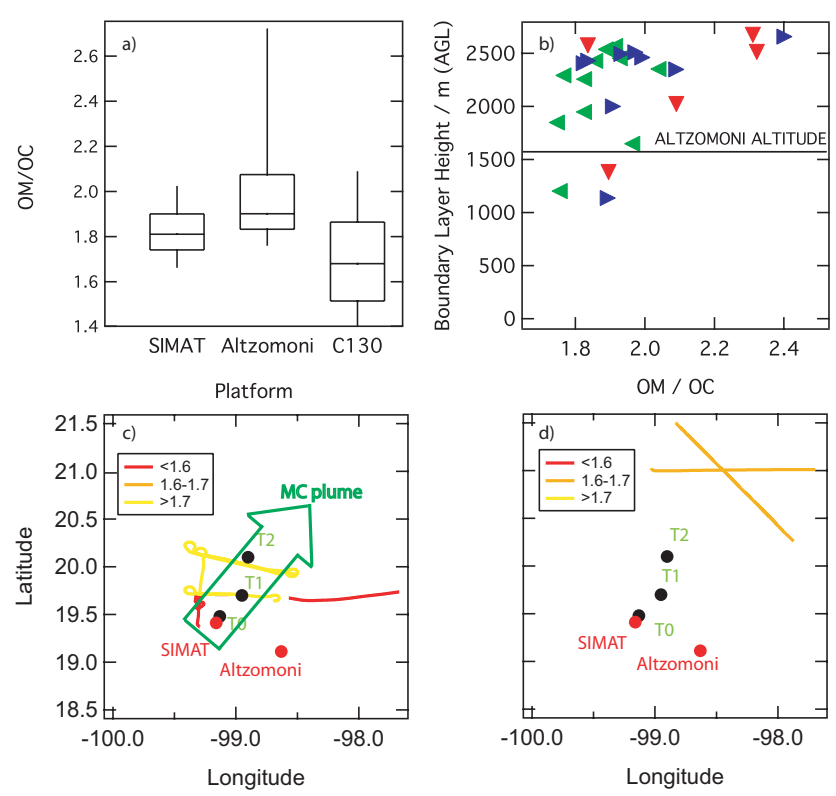

Fig. 8. OM/OC ratios at SIMAT, at Altzomoni, and on the C130 (a). Panel (b) shows OM/OC ratios at Altzomoni as a function of boundary layer height and wind direction (red from the north, blue from the west, and green from the east); panel panel (c) and (d) report C130 flight tracks colored as a function of OM/OC ratio (red $<1.6$, orange between 1.6 and 1.7, and yellow $>1.7$ ); panel (c) shows flight tracks that intercepted the urban plume (green arrow), and panel (d) shows flight tracks that did not intercept the urban plume.

During MIRAGE the concentration of unsaturated aliphatic $\mathrm{C}=\mathrm{C}-\mathrm{H}$ and non-acid cabonyl $\mathrm{C}=\mathrm{O}$ groups were negligible compared to the concentration of saturated aliphatic C-C-H and carboxylic acid $\mathrm{COOH}$ groups, respectively, making the $\mathrm{C}-\mathrm{C}-\mathrm{H}$ group representative of the aliphatic $\mathrm{C}-\mathrm{H}$ fraction and the $\mathrm{COOH}$ group representative of the $\mathrm{C}=\mathrm{O}$ fraction. Figure 9a reports the molar concentration of carboxylic acid versus the molar concentration of aliphatic saturated group at SIMAT and Altzomoni. $\mathrm{COOH}$ and $\mathrm{C}$ $\mathrm{C}-\mathrm{H}$ molar concentrations were normalized to $\mathrm{CO}$ concentration. The carboxylic acid to aliphatic saturated molar ratio was 0.10 at SIMAT (correlation coefficient equal to 0.96) and 0.11 at Altzomoni (correlation coefficient equal to 0.98 ). De Carlo et al. (2008) compute the OM to CO ratio from aircraft measurements and relate it to the age of the particles; in fact OM is expected to increase with SOA formation, while carbon monoxide is a tracer for recent emissions, typically of combustion. The correlation between particle age and $\mathrm{OM}$ to $\mathrm{CO}$ ratio implies that $\mathrm{OM}$ and $\mathrm{CO}$ have a common source so that dilution is compensated by $\mathrm{CO}$ normalization (Kleinman et al., 2008). The OM to CO ratio on the $\mathrm{C} 130$ ranged between 70 and $90 \mu \mathrm{g} \mathrm{m}^{-3} \mathrm{ppm}^{-1}$ (De Carlo et al., 2008). Figure $9 \mathrm{~b}$ shows the $\mathrm{COOH}$ to $\mathrm{C}-\mathrm{C}-\mathrm{H}$ ratios at SIMAT and Altzomoni as a function of the OM to $\mathrm{CO}$ ratio. At SIMAT aged particles characterized by OM to CO larger 

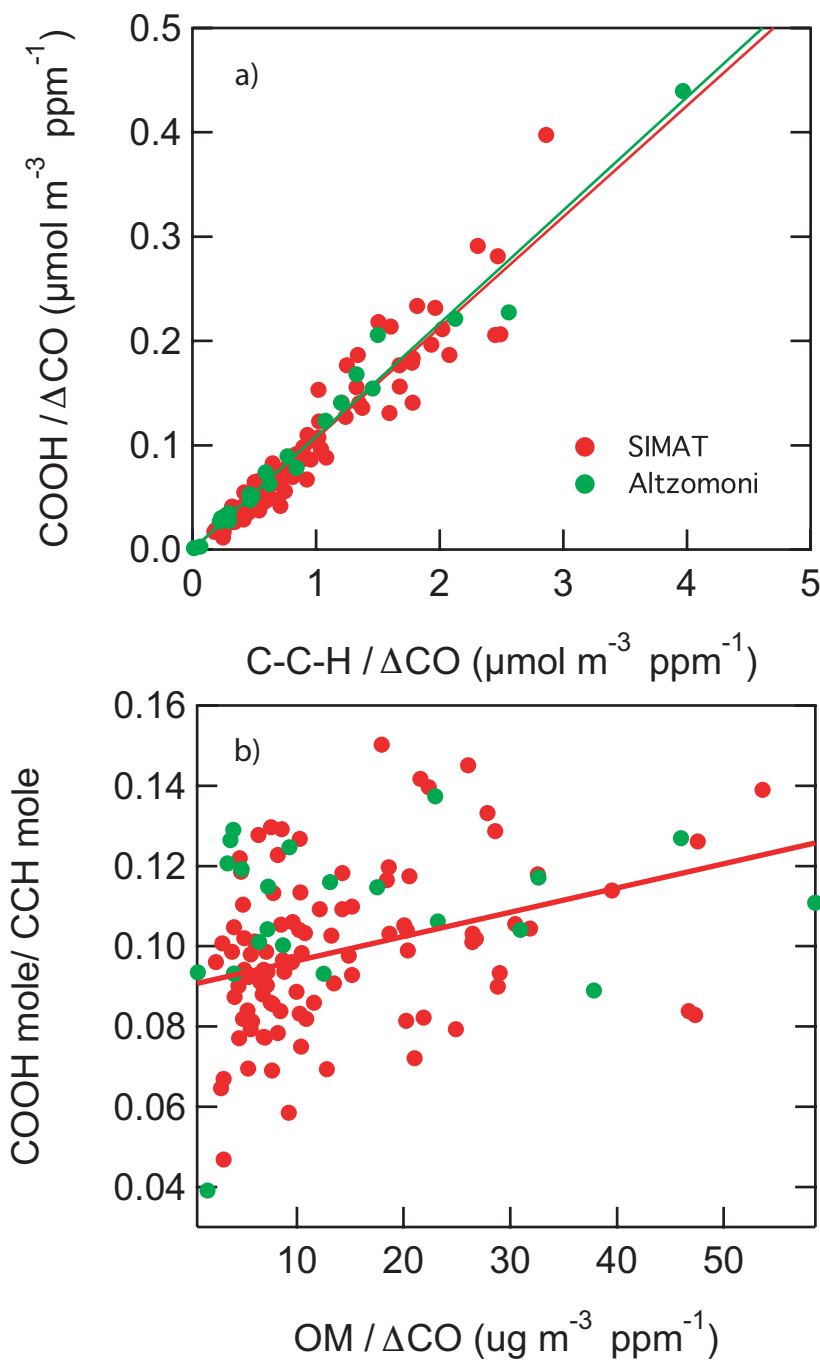

Fig. 9. Panel (a): molar ratios of carboxylic acid group to saturated aliphatic C-C-H group at SIMAT (red) and at Altzomoni (green). Panel (b): $\mathrm{COOH}$ to $\mathrm{C}-\mathrm{C}-\mathrm{H}$ molar ratio as a function of particle age defined by the OM to CO ratio $(r=0.38)$; two outliers with OM/OC larger than 50 are omitted.

than $20 \mu \mathrm{g} \mathrm{m}^{-3} \mathrm{ppm}^{-1}$ had $\mathrm{COOH}$ to C-C-H ratio larger than 0.08 , while smaller ratios were observed for less aged particles. Altzomoni had usually higher $\mathrm{C}=\mathrm{O}$ to $\mathrm{C}-\mathrm{C}-\mathrm{H}$ ratios than SIMAT, likely due to aerosol processing (De Carlo et al., 2008; Maria et al., 2002; Turpin and Lim, 2001). Figure 9b reports the linear fit function of SIMAT measurements and shows a weak correlation $(r=0.34)$ between $\mathrm{COOH}$ to C-C$\mathrm{H}$ ratio and $\mathrm{OM}$ to $\mathrm{CO}$ ratio; considering the wide range of particle sources and their mixtures, this weak correlation explains a significant amount of the variability in the acid fraction. The fitting line has a positive slope consistent with the increase of $\mathrm{COOH}$ to $\mathrm{C}-\mathrm{C}-\mathrm{H}$ ratio with age. The ratio on the $\mathrm{C} 130$ was characterized by a large variability and ranged between $0.030-0.2$ for plume samples and $0.06-0.2$ for background samples.
The $\mathrm{C}=\mathrm{O}$ to $\mathrm{C}-\mathrm{C}-\mathrm{H}$ group ratio was measured with the same technique during ICARTT in summer 2004, without distinction between ketones and carboxylic acids. The $\mathrm{C}=\mathrm{O}$ to $\mathrm{C}-\mathrm{C}-\mathrm{H}$ ratio measured during ICARTT was about 0.5 at the remote platforms located downwind of US continental emissions (Appledore Island in Maine, Chebogue Point in Nova Scotia, and the Ronald H. Brown cruise in New England) and 0.1 on board the CIRPAS Twin Otter in Ohio close to power plant fresh emissions. The Mexico City area was strongly affected by combustion processes (Salcedo et al., 2006; SMADF, 2002, 2003), as reflected in the measured high carbon monoxide concentrations (on average carbon monoxide concentration at SIMAT was $1000 \mathrm{ppb}$ ). Submicron particles collected at SIMAT and in Ohio, which were dominated by combustion emissions, showed similar carbonyl $\mathrm{C}=\mathrm{O}$ to saturated aliphatic $\mathrm{C}-\mathrm{C}-\mathrm{H}$ ratios.

\section{Conclusions}

During the MILAGRO campaign, organic functional groups in the aerosol phase were investigated at an urban site, a high altitude site, and on the NCAR C130. Aliphatic saturated, aliphatic unsaturated, aromatic, alcohol (including sugars, anhydrosugars, polyols), non-acid carbonyl, carboxylic acid, and amine groups were identified. Organic sulfate compounds and organonitrates were always below detection limit.

Organic aerosols at SIMAT and at Altzomoni showed that aliphatic saturated C-C-H group and carboxylic acid $\mathrm{COOH}$ group dominated the organic mass (OM). Similar average composition of the OM were observed at the two sites with maxima of Altzomoni OM concentration during cold surge episodes that flushed the basin towards the south. FTIR sampling periods overlapped mostly with the periods when the Altzomoni site was inside the mixing layer. Concentration and composition of $\mathrm{OM}$ at the mountain site can be assigned to the influence of polluted air masses from the surrounding valleys. On average SIMAT showed 1.5 to 2 times higher OM compared to Altzomoni.

Samples collected on the aircraft exhibit different composition as a function of location relative to the city basin: alcohol group was more abundant north of the city. C130 background samples showed a smaller fraction of oxygenated functional groups and a larger fraction of aliphatic saturated group compared to samples collected inside the urban plume.

XRF elemental analysis of samples collected at SIMAT identified some of the sources of the organic aerosol. Using non-soil $\mathrm{K}$ as a tracer, we estimated the upper bound of the average contribution of biomass burning to the submicron organic carbon on the order of 30 to $40 \%$, at the upper end of results obtained by source apportionment studies and single particle measurements at T0 (Aiken et al., 2009; Moffet et al., 2008; Stone et al., 2008). 
The average OM/OC ratio was higher at Altzomoni compared to the urban site, as a consequence of the larger contribution of oxidized functional groups. The small variability of the OM/OC ratio in Mexico City (SIMAT) indicates a uniform composition of the organic fraction throughout the entire sampling campaign. At Altzomoni the highest OM/OC values were observed for samples collected under the likely influence of Mexico City outflow, as indicated by boundary layer height and wind direction. Although the number of samples collected when the site was outside the Mexico City mixing layer was limited, the FTIR results showed that Mexico City outflow had a higher oxidized character than the aerosol sampled outside the mixing-layer. The $\mathrm{OM} / \mathrm{OC}$ ratio measured by the aircraft inside the urban plume showed a large variability with smaller values close to the city.

The average carboxylic acid to aliphatic saturated molar ratios at SIMAT and Altzomoni were about 0.1, similar to the values observed in Ohio during the ICARTT campaign. At SIMAT the molar ratio varied between 0.04 and 0.14 , and ratios higher than 0.08 were observed for most aged particles, as indicated by the $\mathrm{OM}$ to $\mathrm{CO}$ ratios.

Acknowledgements. Grant support for this work was provided by NSF (ATM 05-11772), the James S. McDonnell Foundation, and DOE/NICCR-NIGEC (W/GEC05-010 and MPC35TA-A5). In addition we are grateful to Andreas Stohl for compiling FLEXPART analysis, and to Greg Kok, John Walker, Rafael Ramos, and the NCAR C130 crew for valuable assistance during sample collection.

\section{References}

Aiken, A. C., De Carlo, P. F., and Jimenez, J. L.: Elemental analysis of organic species with Electron Ionization HighResolution Mass Spectrometry, Anal. Chem., 79, 8350-8358, doi:10.1021/ac071150w, 2007.

Aiken, A. C., De Carlo, P. F., Kroll, J. H., Worsnop, D. R., Huffman, J. A., Docherty, K. S., Ulbrich, I. M., Mohr, C., Kimmel, J. R., Sueper, D., Sun, Y., Zhang, Q., Trimborn, A., Northway, M., Ziemann, P. J., Canagaratna, M. R., Onasch, T. B., Alfarra, M. R., Prevot, A. S. H., Dommen, J., Duplissy, J., Metzger, A., Baltensperger, U., and Jimenez, J. L.: O/C and OM/OC Ratios of Primary, Secondary, and Ambient Organic Aerosols with HighResolution Time-of-Flight Aerosol Mass Spectrometry, Environ. Sci. Technol, 42, 4478-4485, doi:10.1021/es703009q, 2008.

Aiken, A. C., Salcedo, D., Cubison, M. J., Huffman, J. A., DeCarlo, P. F., Ulbrich, I. M., Docherty, K. S., Sueper, D., Kimmel, J. R., Worsnop, D. R., Trimborn, A., Northway, M., Stone, E. A., Schauer, J. J., Volkamer, R., Fortner, E., de Foy, B., Wang, J., Laskin, A., Shutthanandan, V., Zheng, J., Zhang, R., Gaffney, J., Marley, N. A., Paredes-Miranda, G., Arnott, W. P., Molina, L. T., Sosa, G., and Jimenez, J. L.: Mexico City aerosol analysis during MILAGRO using high resolution aerosol mass spectrometry at the urban supersite (T0) - Part 1: Fine particle composition and organic source apportionment, Atmos. Chem. Phys. Discuss., 9, 8377-8427, 2009,

http://www.atmos-chem-phys-discuss.net/9/8377/2009/.
Allan, J. D., Alfarra, M. R., Bower, K. N., Williams, P. I., Gallagher, W. M., Jimenez, J. L., McDonald, A. G., Nemitz, E., Canagaratna, M. R., Jayne, J. T., Coe, H., and Worsnop, D. R.: Quantitative sampling using an Aerodyne aerosol mass spectrometer 2. Measurements of fine particulate chemical composition in two U.K. cities, J. Geophys. Res., 4091-4108, doi:10.1029/2002JD002359, 2003.

Allan, J. D., Delia, A. E., Coe, H., Bower, K. N., Alfarra, R., M., Jimenez, L., J., Middlebrook, M., A., Drewnick, F., Onasch, T. B., Canagaratna, M. R., Jayne, J. T., and Worsnop, D. R.: A generalized method for the extraction of chemically resolved mass spectra from Aerodyne aerosol mass spectrometer data, J. Aerosol Sci, 35, 909-922, 2004.

Andreae, M. and Merlet, P.: Emission of trace gases and trace gases and aerosols from biomass burning, Global Biogeochem. Cy., 15, 955-966, 2001.

Aymoz, G., Jaffrezo, J. L., Chapuis, D., Cozic, J., and Maenhaut, W.: Seasonal variation of $\mathrm{PM}_{10}$ main constituents in two valleys of the French Alps. I: EC/OC fractions, Atmos. Chem. Phys., 7, 661-675, 2007,

http://www.atmos-chem-phys.net/7/661/2007/.

Baumgardner, D., Grutter, M., Allan, J., Ochoa, C., Rappenglueck, B., Russell, L. M., and Arnott, W. P.: Physical and chemical properties of the mixed layer in the region of the Mexico Megapolis, Atmos. Chem. Phys. Discuss., submitted, 2009.

Beaton, S. P., Bishop, G. A., and Stedman, D. H.: Emission characteristics of Mexico City vehicles, Air and Waste, 42, 1424-1429, 1992.

Canagaratna, M. R., Jimenez, J. L., Allan, J. D., Alfarra, M. R., Zhang, Q., Onasch, T. B., Drewnick, F., Coe, H., Middlebrook, A., Delia, A., Williams, L. R., Trimborn, A. M., Northway, M. J., De Carlo, P. F. andKolb, C. E., Davidovits, P., and Worsnop, D. R.: Chemical and microphysical characterization of ambient aerosols with the aerodyne aerosol mass spectrometer, Mass Spectrom. Rev., 26, 185-222, 2007.

Chan, Y. C., Simpson, R. W., McTainsh, G. H., Vowles, P. D., Cohen, D. D., and Bailey, G. M.: Source apportionment of visibility degradation problems in Brisbane (Australia) using the multiple linear regression techniques, Atmos. Environ., 33, 3237-3250, 1999.

Charlson, R. J., Schwartz, S. E., Hales, J. M., Cess, R. D., Coakley, J. A., J., Hansen, J. E., and Hofmann, D. J.: Climate Forcing by Anthropogenic Aerosols, Science, 255, 423-430, 1992.

Chow, J., Watson, J., Edgerton, S., and Vega, E.: Chemical composition of PM2. 5 and PM10 in Mexico City during winter 1997, Sci. Total Environ., 287, 177-201, 2002.

Crounse, J. D., DeCarlo, P. F., Blake, D. R., Emmons, L. K., Campos, T. L., Apel, E. C., Clarke, A. D., Weinheimer, A. J., McCabe, D. C., Yokelson, R. J., Jimenez, J. L., and Wennberg, P. O.: Biomass burning and urban air pollution over the Central Mexican Plateau, Atmos. Chem. Phys. Discuss., 9, 2699-2734, 2009 , http://www.atmos-chem-phys-discuss.net/9/2699/2009/.

Day, D. A., Takahama, S., Gilardoni, S. G., and Russell, L. M.: Organic composition of single and submicron particles in different regions of western North America and the eastern Pacific during INTEX-B 2006, Atmos. Chem. Phys., 9, 5433-5446, 2009, http://www.atmos-chem-phys.net/9/5433/2009/.

de Foy, B., Fast, J. D., Paech, S. J., Phillips, D., Walters, J. T., 
Coulter, R. L., Martin, T. J., Pekour, M. S., Shaw, W. J., Kastendeuch, P. P., Marley, N. A., Retama, A., and Molina, L. T.: Basinscale wind transport during the MILAGRO field campaign and comparison to climatology using cluster analysis, Atmos. Chem. Phys., 8, 1209-1224, 2008,

http://www.atmos-chem-phys.net/8/1209/2008/.

De Carlo, P., Kimmel, J., Trimborn, A., Northway, M., Aiken, J., Gonin, M., Fuhrer, K., Horvath, K., Docherty, K., Worsnop, D., and Jimenez, J. L.: Field-deployable, high-resolution, time-offlight aerosol mass spectrometer, Anal. Chem., 24, 8281-8289, 2006.

DeCarlo, P. F., Dunlea, E. J., Kimmel, J. R., Aiken, A. C., Sueper, D., Crounse, J., Wennberg, P. O., Emmons, L., Shinozuka, Y., Clarke, A., Zhou, J., Tomlinson, J., Collins, D. R., Knapp, D., Weinheimer, A. J., Montzka, D. D., Campos, T., and Jimenez, J. L.: Fast airborne aerosol size and chemistry measurements above Mexico City and Central Mexico during the MILAGRO campaign, Atmos. Chem. Phys., 8, 4027-4048, 2008, http://www.atmos-chem-phys.net/8/4027/2008/.

Doran, J. C., Barnard, J. C., Arnott, W. P., Cary, R., Coulter, R., Fast, J. D., Kassianov, E. I., Kleinman, L., Laulainen, N. S., Martin, T., Paredes-Miranda, G., Pekour, M. S., Shaw, W. J., Smith, D. F., Springston, S. R., and Yu, X.-Y.: The T1-T2 study: evolution of aerosol properties downwind of Mexico City, Atmos. Chem. Phys., 7, 1585-1598, 2007,

http://www.atmos-chem-phys.net/7/1585/2007/.

Duan, M., Zhuang, G., Li, X., Tao, H., and Zhuang, Y.: The characteristics of carbonaceous species and their sources in $\mathrm{PM}_{2.5}$ in Beijing, Atmos. Environ., 38, 1275-1282, 2004.

Edgerton, S. A., Arriaga, J. L., Archuleta, J., Bian, X., Bossert, J. E., Chow, J. C., Coulter, R., Doran, J. C., Doskey, P. V., Elliott, S., Fast, J. D., Gaffney, J. S., Guzman, F., Hubbe, J., Lee, J. T., Malone, N. A., McNair, L. A., Neff, W., Ortiz, E., Petty, R., Ruiz, M., Shaw, W. J., Sosa, G., Vega, E., Watson, J. G., Whiteman, C. D., and Zhong, S.: Particulate air pollution, J. Air Waste Manage., 49, 1221-1229, 1999.

El-Zanan, H., Lowenthal, D., Zielinska, B., Chow, J., and Kumar, N.: Determination of the organic aerosol mass to organic carbon ratio in IMPROVE samples, Chemosphere, 60, 485-496, 2005.

Emeis, S., Jahn, C., Munkel, C., Munsterer, C., and Schafer, K.: Multiple atmospheric layering and mixing-layer height in the Inn valley observed by remote sensing, Meteorol. Z., 16, 415-424, 2007.

Fast, J. D., de Foy, B., Acevedo Rosas, F., Caetano, E., Carmichael, G., Emmons, L., McKenna, D., Mena, M., Skamarock, W., Tie, X., Coulter, R. L., Barnard, J. C., Wiedinmyer, C., and Madronich, S.: A meteorological overview of the MILAGRO field campaigns, Atmos. Chem. Phys., 7, 2233-2257, 2007, http://www.atmos-chem-phys.net/7/2233/2007/.

Fine, P. M., Cass, G. R., and Simoneit, B. R. T.: Chemical Characterization of Fine Particle Emissions from the Fireplace Combustion of Woods Grown in the Southern United States, Environ. Sci. Technol, 36, 1442-1451, doi:10.1021/es0108988, 2002.

Gilardoni, S., Russell, L. M., Sorooshian, A., Flagan, R. C., Seinfeld, J. H., Bates, T. S., Quinn, P. K., Allan, J. D., Williams, B., Goldstein, A. H., Onasch, T. B., and Worsnop, D. R.: Regional variation of organic functional groups in aerosol particles on four U.S. east coast platforms during the International Consortium for Atmospheric Research on Transport and Trans- formation 2004 campaign, J. Geophys. Res., 112, D10S27, doi:10.1029/2006JD007737, 2007.

Graham, B., Mayol-Bracero, O. L., Guyon, P., Roberts, G. C., Decesari, S., Facchini, M. C., Artaxo, P., Maenhaut, W., Ka, P., and Andreae, M. O.: Water-soluble organic compounds in biomass burning aerosols over Amazonia1. Characterization by NMR and GC-MS, J. Geophys. Res., 107, 8047, doi:10.1029/2001JD000336, 2002.

Grutter, M., Basaldud, R., Rivera, C., Harig, R., Junkerman, W., Caetano, E., and Delgado-Granados, $\mathrm{H} .: \mathrm{SO}_{2}$ emissions from Popocatépetl volcano: emission rates and plume imaging using optical remote sensing techniques, Atmos. Chem. Phys., 8, 6655-6663, 2008,

http://www.atmos-chem-phys.net/8/6655/2008/.

Hildemann, L. M., Mazurek, M. A., Cass, G. R., and Simoneit, B. R. T.: Seasonal Trends in Los Angeles Ambient Organic Aerosol Observed by High-Resolution Gas Chromatography, Aerosol Sci. Tech., 20, 303-317, 1994.

Jayne, J. T., Leard, D. C., Zhang, X., Davidovits, P., S., A., K., Kolb, C. E., and Worsnop, D. R.: Development of an aerosol mass spectrometer for size and composition analysis of submicron particles, Aerosol Sci. Tech., 33, 49-70, 2000.

Jimenez, J. L., Jayne, J. T., Shi, Q., Kolb, C. E., Worsnop, D. R., Yourshaw, I., Seinfeld, J. H., Flagan, R. C., Zhang, X., Smith, K. A., Morris, J. W., and Davidovits, P.: Ambient aerosol sampling using the Aerodyne Aerosol Mass Spectrometer, J. Geophys. Res., 108, SOS13-1-SOS13-13, doi:10.1029/ 2001JD001213, 2003.

Johnson, K. S., de Foy, B., Zuberi, B., Molina, L. T., Molina, M. J., Xie, Y., Laskin, A., and Shutthanandan, V.: Aerosol composition and source apportionment in the Mexico City Metropolitan Area with PIXE/PESA/STIM and multivariate analysis, Atmos. Chem. Phys., 6, 4591-4600, 2006,

http://www.atmos-chem-phys.net/6/4591/2006/.

Jordan, T. B. and Seen, A. J.: Effect of airflow setting on the organic composition of woodheater emissions, Environ. Sci. Technol, 39, 3601-3610, 2005.

Kang, C.-M., Kang, B.-W., and Lee, H. S.: Source identification and trends in concentrations of gaseous and fine particulate principal species in Seoul, South Korea, J. Air Waste Manage., 56, 911921, 2006.

Kawamura, K. and Ikushima, K.: Seasonal changes in the distribution of dicarboxylic acids in the urban atmosphere, Environ. Sci. Technol, 27, 2227-2235, doi:10.1021/es00047a033, 1993.

Kawamura, K. and Yasui, O.: Diurnal changes in the distribution of dicarboxylic acids, ketocarboxylic acids and dicarbonyls in the urban Tokyo atmosphere, Atmos. Environ., 39, 1945-1960, doi:10.1016/j.atmosenv.2004.12.014, 2005.

Kiss, G., Varga, B., Galambos, I., and Ganszky, I.: Characterization of water-soluble organic matter isolated from atmospheric fine aerosol, J. Geophys. Res., 107, 8339, doi:10.1029/2001JD000603, 2002.

Kleinman, L. I., Springston, S. R., Daum, P. H., Lee, Y.-N., Nunnermacker, L. J., Senum, G. I., Wang, J., Weinstein-Lloyd, J., Alexander, M. L., Hubbe, J., Ortega, J., Canagaratna, M. R., and Jayne, J.: The time evolution of aerosol composition over the Mexico City plateau, Atmos. Chem. Phys., 8, 1559-1575, 2008, http://www.atmos-chem-phys.net/8/1559/2008/.

Kowalczyk, G. S., Gordon, G. E., and Rheingrover, S. W.: Iden- 
tification of atmospheric particulate sources in Washington, DC using chemical element balances, Environ. Sci. Technol, 16, 7990, doi:10.1021/es00096a005, 1982.

Lindberg, J. D.: Composition and optical absorption coefficient of atmospheric particulate matter, Opt. Quant. Electron., 7, 131139, 1975.

Liu, S., Takahama, S., Russell, L. M., Gilardoni, S., and Baumgardner, D.: Oxygenated organic functional groups and their sources in single and submicron organic particles in MILAGRO 2006 campaign, Atmos. Chem. Phys. Discuss., 9, 4567-4607, 2009, http://www.atmos-chem-phys-discuss.net/9/4567/2009/.

Maenhaut, W. and Cafmeyer, J.: Particle induced x-ray emission analysis and multivariate techniques: an application to the study of the sources of respirable atmospheric particles in Ghent, Belgium, J. Trace Microprobe T., 5, 135-158, 1987.

Maria, S. F., Russell, L. M., Turpin, B. J., and Porcja, R. J.: FTIR measurements of functional groups and organic mass in aerosol samples over the Caribbean, Atmos. Environ., 36, 5185-5196, 2002.

Maria, S. F., Russell, L. M., Turpin, B. J., Porcja, R. J., Campos, T. L., Weber, R. J., and Huebert, B. J.: Source signatures of carbon monoxide and organic functional groups in Asian Pacific Regional Aerosol Characterization Experiment (ACE-Asia) submicron aerosol types, J. Geophys. Res., 108, ACE 5-1-ACE 5-14, doi:10.1029/2003JD003703, 2003.

Marquez, C., Castro, T., Muhlia, A., Moya, M., Martinez-Arroyo, A., and Baez, A.: Measurement of aerosol particles, gases and flux radiation in the Pico de Orizaba National Park, and its relationship to air pollution transport, Atmos. Environ., 39, 38773890, 2005.

Mayol-Bracero, O. L., Guyon, P., Graham, B., Roberts, G., Andreae, M. O., Decesari, S., Facchini, M. C., Fuzzi, S., and Artaxo, P.: Water-soluble organic compounds in biomass burning aerosols over Amazonia 2. Apportionment of the chemical composition and importance of the polyacidic fraction, J. Geophys. Res., 107, 8091, doi:10.1029/2001JD000522, 2002.

McFiggans, G., Artaxo, P., Baltensperger, U., Coe, H., Facchini, M. C., Feingold, G., Fuzzi, S., Gysel, M., Laaksonen, A., Lohmann, U., Mentel, T. F., Murphy, D. M., O’Dowd, C. D., Snider, J. R., and Weingartner, E.: The effect of physical and chemical aerosol properties on warm cloud droplet activation, Atmos. Chem. Phys., 6, 2593-2649, 2006,

http://www.atmos-chem-phys.net/6/2593/2006/.

Miranda, J., Cahill, T. A., Morales, J. R., Aldape, F., Flores M, J., and Diaz, R. V.: Determination of elemental concentrations in atmospheric aerosols in Mexico City using proton induced x-ray emission, proton elastic scattering, and laser absorption, Atmos. Environ., 28, 2299-2306, 1994.

Miranda, J., Andrade, E., Lopez-Suarez, A., Ledesma, R., Cahill, T. A., and Wakabayashi, P. H.: A receptor model for atmospheric aerosols from a southwestern site in Mexico City, Atmos. Environ., 30, 3771-3479, 1996.

Miranda, J., Barrera, V. A., Espinosa, A. A., Galindo, O. S., NunezOrosco, A., Montesinos, R. C., Leal-Castro, A., and Meinguer, J.: PIXE analysis of atmospheric aerosols from three sites in Mexico City, Instruments and Methods in Physics Research, Section B: Beam Interactions with Materials and Atoms, 157-160, 2004.

Moffet, R. C., de Foy, B., Molina, L. T., Molina, M. J., and Prather,
K. A.: Measurement of ambient aerosols in northern Mexico City by single particle mass spectrometry, Atmos. Chem. Phys., 8, 4499-4516, 2008,

http://www.atmos-chem-phys.net/8/4499/2008/.

Molina, L. T., Kolb, C. E., de Foy, B., Lamb, B. K., Brune, W. H., Jimenez, J. L., Ramos-Villegas, R., Sarmiento, J., ParamoFigueroa, V. H., Cardenas, B., Gutierrez-Avedoy, V., and Molina, M. J.: Air quality in North America's most populous city overview of the MCMA-2003 campaign, Atmos. Chem. Phys., 7, 2447-2473, 2007,

http://www.atmos-chem-phys.net/7/2447/2007/.

Molina, L. T., Madronich, S., Gaffney, J. S., and Singh, H. B.: Overview of MILAGRO/INTEX-B Campaign, IGAC News Letter, 38, 2-15, 2008.

Molina, M. J. and Molina, L. T.: Air Quality in Mexico Megacity: An Integrated Assessment, 384 pp., 2002.

O'Brien, R. J., Crabtree, J. H., Holmes, J. R., Hoggan, M. C., and Bocklan, A. H.: Formation of photochemical aerosol from hydrocarbons, Environ. Sci. Technol, 9, 577-582, 1975a.

O'Brien, R. J., Holmes, J. R., and Bocklan, A. H.: Formation of photochemical aerosol from hydrocarbons Chemical reactivity and products, Environ. Sci. Technol, 9, 586-576, 1975b.

Pope, C. A., r., Thun, M. J., Namboodiri, M. M., Dockery, D. W., Evans, J. S., Speizer, F. E., and Heath, C. W. J.: Particulate air pollution as a predictor of mortality in a prospective study of U.S. adults, Am, J. Resp. Crit. Care, 151, 669-674, 1995.

Putaud, J. P., Raes, F., Van Dingenen, R., Bruggemann, E., Facchini, M. C., Decesari, S., Fuzzi, S., Gehrig, R., Huglin, C., Laj, P., Lorbeer, G., Maenhaut, W., Mihalopoulos, N., Muller, K., Querol, X., Rodriguez, S., Schneider, J., Spindler, G., ten Brink, H., Torseth, K., and Wiedensohler, A.: A European aerosol phenomenology - 2: chemical characteristics of particulate matter at kerbside, urban, rural and background sites in Europe, Atmos. Environ., 38, 2579-2595, 2004.

Querol, X., Pey, J., Minguillón, M. C., Pérez, N., Alastuey, A., Viana, M., Moreno, T., Bernabé, R. M., Blanco, S., Cárdenas, B., Vega, E., Sosa, G., Escalona, S., Ruiz, H., and Artñano, B.: PM speciation and sources in Mexico during the MILAGRO-2006 Campaign, Atmos. Chem. Phys., 8, 111-128, 2008, http://www.atmos-chem-phys.net/8/111/2008/.

Raga, G. B., Kok, G. L., Baumgardner, D., Baez, A., and Rosas, I.: Evidence for Volcanic Influence on Mexico City Aerosols, Geophys. Res. Lett., 26, 1149-1152, doi:10.1029/1999GL900154, 1999.

Rivera, C., Sosa, G., Wöhrnschimmel, H., de Foy, B., Johansson, M., and Galle, B.: Tula industrial complex (Mexico) emissions of $\mathrm{SO}_{2}$ and $\mathrm{NO}_{2}$ during the MCMA 2006 field campaign using a Mini-DOAS system, Atmos. Chem. Phys. Discuss., 9, 51535176, 2009,

http://www.atmos-chem-phys-discuss.net/9/5153/2009/.

Robinson, A., Donahue, N. M., Shrivastava, M. K., Weitkamp, E. A., Sage, A. M., Grieshop, A. P., Lane, T. E., Pierce, J. R., and Pandis: Rethinking organic aerosols: semivolatile emissions and photochemical aging, Science, 315, 1259-1262, 2007.

Rogge, W. F., Hildemann, L. M., Mazurek, M. A., and Cass, G. R.: Sources of Fine Organic Aerosol. 9. Pine, Oak, and Synthetic Log Combustion in Residential Fireplaces, Environ. Sci. Technol, 32, 13-22, doi:10.1021/es960930b, 1998.

Russell, L. M.: Aerosol Organic-Mass-to-Organic-Carbon Ra- 
tio Measurements, Environ. Sci. Technol, 37, 2982-2987, doi:10.1021/es026123w, 2003.

Russell, L. M., Takahama, S., Liu, S., Hawkins, L. N., Covert, D. S., Quinn, P. K., and Bates, T. S.: Oxigenated fraction and mass of organic aerosol from direct emission and atmospheric processing collected on the R/V Ronald Brown during TEXAQS/GoMACCS 2006, J. Geophys. Res, 114, D00F05, doi:10.1029/2008JD011275, 2009.

Salcedo, D., Onasch, T. B., Dzepina, K., Canagaratna, M. R., Zhang, Q., Huffman, J. A., DeCarlo, P. F., Jayne, J. T., Mortimer, P., Worsnop, D. R., Kolb, C. E., Johnson, K. S., Zuberi, B., Marr, L. C., Volkamer, R., Molina, L. T., Molina, M. J., Cardenas, B., Bernabé, R. M., Márquez, C., Gaffney, J. S., Marley, N. A., Laskin, A., Shutthanandan, V., Xie, Y., Brune, W., Lesher, R., Shirley, T., and Jimenez, J. L.: Characterization of ambient aerosols in Mexico City during the MCMA-2003 campaign with Aerosol Mass Spectrometry: results from the CENICA Supersite, Atmos. Chem. Phys., 6, 925-946, 2006, http://www.atmos-chem-phys.net/6/925/2006/.

Saxena, P. and Hildemann, L. M.: Water-soluble organics in atmospheric particles: a critical review of the literature and application of thermodynamics to identify candidate compounds, J. Atmos. Chem., 24, 57-109, 1996.

Seinfeld, J. H. and Pandis, S. N.: Atmospheric chemistry and physics: from air pollution to climate change, 1326 pp., 1998.

Shaw, W. J., Pekour, M. S., Coulter, R. L., Martin, T. J., and Walters, J. T.: The daytime mixing layer observed by radiosonde, profiler, and lidar during MILAGRO, Atmos. Chem. Phys. Discuss., 7, 15025-15065, 2007,

http://www.atmos-chem-phys-discuss.net/7/15025/2007/.

Simoneit, B. R. T., Elias, V. O., Kobayashi, M., Kawamura, K., Rushdi, A., Medeiros, P. M., Rogge, W. F., and Didyk, B. M.: Sugars-Dominant Water-Soluble Organic Compounds in Soils and Characterization as Tracers in Atmospheric Particulate Matter, Environ. Sci. Technol, 38, 5939-5949, 2004a.

Simoneit, B. R. T., Kobayashi, M., Mochida, M., Kawamura, K., Lee, M., Lim, H.-J., Turpin, B. J., and Komazaki, Y.: Composition and major sources of organic compounds of aerosol particulate matter sampled during the ACE-Asia campaign, J. Geophys. Res, 109, 1-22, 2004b.

Simpson, D., Yttri, K. E., Klimont, Z., Kupiainen, K., Caseiro, A., Gelencser, A., Pio, C., Puxbaum, H., and Legrand, M.: Modeling carbonaceous aerosol over Europe: Analysis of the CARBOSOL and EMEP EC/OC campaigns, J. Geophys. Res., 112, D23S14, doi:10.1029/2006JD008158, 2007.

SMADF: Inventario de Emisiones a la Atmosfera. Zona Metropolitana del Valle de Mexico, 2000, online available at: http://www. sma.df.gob.mx, 2002.

SMADF: Informe del Estado de la Calidad del Ayre y Tendencias para la Zona Metropolitana del Valle del Mexico, online available at: http://www.sma.df.gob.mx, 2003.
Stone, E. A., Snyder, D. C., Sheesley, R. J., Sullivan, A. P., Weber, R. J., and Schauer, J. J.: Source apportionment of fine organic aerosol in Mexico City during the MILAGRO experiment 2006, Atmos. Chem. Phys., 8, 1249-1259, 2008, http://www.atmos-chem-phys.net/8/1249/2008/.

Tie, X., Madronich, S., Li, G., Ying, Z., Weinheimer, A., Apel, E., and Campos, T.: Simulation of Mexico City plumes during the MIRAGE-Mex field campaign using the WRF-Chem model, Atmos. Chem. Phys. Discuss., 9, 9221-9266, 2009, http://www.atmos-chem-phys-discuss.net/9/9221/2009/.

Turpin, B. J. and Lim, H.-J.: Species contributions to PM2..5 mass concentrations: revisiting common assumptions for estimating organic mass, Aerosol Sci. Tech., 35, 602-610, 2001.

Vega, E., Mugica, V., Reyes, E., Sanchez, G., Chow, J. C., and Watson, J. G.: Chemical composition of fugitive dust emitters in Mexico City, Atmospheric, Atmos. Environ., 35, 4033-4039, 2001.

Watson, J. G. and Chow, J. C.: Source characterization of major emission sources in the Imperial and Mexicali Valleys along the US/Mexico border, Sci. Total Environ., 276, 33-47, 2001.

Yokelson, R. J., Urbanski, S. P., Atlas, E. L., Toohey, D. W., Alvarado, E. C., Crounse, J. D., Wennberg, P. O., Fisher, M. E., Wold, C. E., Campos, T. L., Adachi, K., Buseck, P. R., and Hao, W. M.: Emissions from forest fires near Mexico City, Atmos. Chem. Phys., 7, 5569-5584, 2007, http://www.atmos-chem-phys.net/7/5569/2007/.

Zhang, Q., Jimenez, J. L., Canagaratna, M. R., Allan, J. D., Coe, H., Ulbrich, I., Alfarra, M. R., Takami, A., Middlebrook, A. M., Sun, Y. L., Dzepina, K., Dunlea, E., Docherty, K., De Carlo, P. F., Salcedo, D., Onasch, T., Jayne, J. T., Miyoshi, T., Shimono, A., Hatakeyama, S., Takegawa, N., Kondo, Y., Schneider, J., Drewnick, F., Borrmann, S., Weimer, S., Demerjian, K., Williams, P., Bower, K., Bahreini, R., Cottrell, L., Griffin, R. J., Rautiainen, J., Sun, J. Y., Zhang, Y. M., and Worsnop, D. R.: Ubiquity and dominance of oxygenated species in organic aerosols in anthropogenically-influenced Northern Hemisphere midlatitudes, Geophys. Res. Lett., 34, L13801, doi:10.1029/2007GL029979, 2007.

Zhang, X., Smith, K. A., Worsnop, D. R., Jimenez, J. L., Jayne, J. T., and Kolb, C. E.: A numerical characterization of particle beam collimation by an aerodynamic lens-nozzle system: part I. An individual lens or nozzle, Aerosol Sci. Tech., 36, 617-631, 2002.

Zhang, X., Smith, K. A., Worsnop, D. R., Jimenez, J. L., Jayne, J. T., Kolb, C. E., Morris, J. W., and Davidovits, P.: Numerical characterization of particle beam collimation: Part II integrated aerodynamic-lens-nozzle system, Aerosol Sci. Tech., 36, 619638,2004 